
Information Sciences Division Argonne National Laboratory 


\section{Argonne National Laboratory}

Argonne National Laboratory, with facilities in the states of Illinois and Idaho, is owned by the United States govemment, and operated by the University of Chicago under the provisions of a contract with the Department of Energy.

This technical memo is a product of Argonne's Environmental Assessment and Information Sciences (EAIS) Division. For information on the division's scientific and engineering activities, contact:

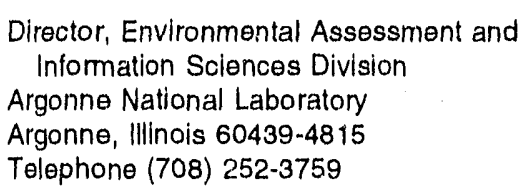

Presented in this technical memo are preliminary results of ongoing work or work that is more limited in scope and depth than that described in formal reports issued by the EAIS Division.

\section{Disclaimer}

This report was prepared as an account of work sponsored by an agency of the United States Government. Neither the United States Government nor any agency thereof, nor any of their employees, makes any warranty, express or implied, or assumes any legal liability or responsibility for the accuracy, completeness, or usefulness of any information, apparatus, product, or process disclosed, or represents that its use would not infringe privately owned rights. Reference herein to any specific commercial product, process, or service by trade name, trademark, manufacturer, or otherwise, does not necessarily constitute or imply its endorsement, recommendation, or favoring by the United States Govemment or any agency thereot. The views and opinions of authors expressed herein do not necessarily state or reflect those of the United States Government or any agency thereof.

Available to DOE and DOE contractors from the Office of Scientific and Tochnical Information, P.O. Box 62, Oak Ridge, TN 37831; prices available from (615) 576.8401 , FTS 626-8401

Available to the public from the National Technical Information Senvice, U.S. Department of Commerce, 5285 Port Royal Road, Springfield, VA 22161. 


\section{Update of Identification and Estimation of Socioeconomic Impacts Resulting from Perceived Risks and Changing Images: An Annotated Bibliography}

by L.A. Nieves, D.E. Clark, and D. Wernette

Environmental Assessment and Information Sciences Division, Argonne National Laboratory, 9700 South Cass Avenue, Argonne, Illinois 60439

Work sponsored by United States Department of Energy, Yucca Mountain Site Characterization Project Office 


\section{CON'TENTS}

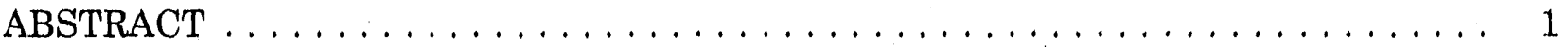

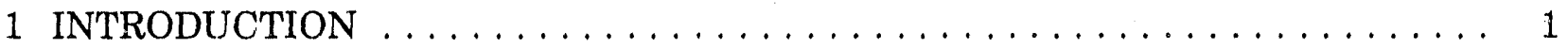

2 SUMMARY AND LITERATURE REVIEW $\ldots \ldots \ldots \ldots \ldots \ldots \ldots \ldots$

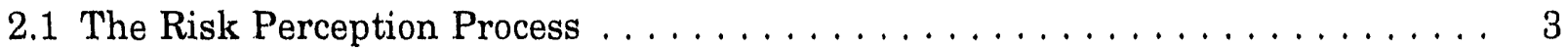

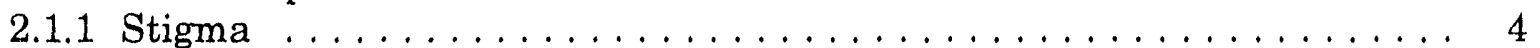

2.1 .2 State of Nevada Studies $\ldots \ldots \ldots \ldots \ldots \ldots \ldots \ldots \ldots \ldots \ldots$

2.2 Relationship Between Risk Perception and Economic Impacts . . . . . . . . . 4

2.2 .1 Perceived Risks . . . . . . . . . . . . . . . . . . . . . . . . 4

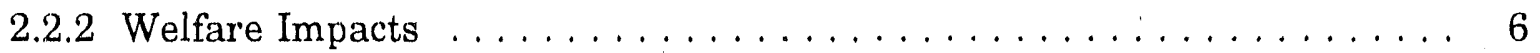

2.3 Economic Methods and Empirical Applications $\ldots \ldots \ldots \ldots \ldots \ldots$

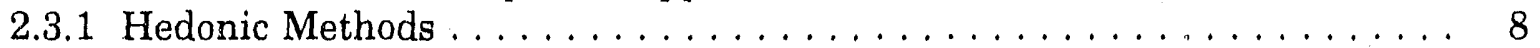

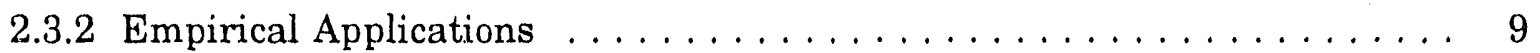

2.4 Interregional Market Interactions and Adjustments . . . . . . . . . . . 10

2.4.1 Amenities versus Employment as Determinants of Migration . . . . . . . . 11

2.4.2 Relationship between Migration, Wages, and Property Values . . . . . . . . 11

3 WORKING BIBLIOGRAPHY $\ldots \ldots \ldots \ldots \ldots \ldots \ldots \ldots \ldots$

4 TOPICAL INDEX TO ABSTRACTS $\ldots \ldots \ldots \ldots \ldots \ldots \ldots \ldots \ldots \ldots$

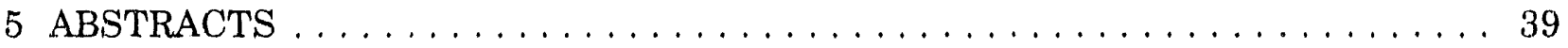




\title{
UPDATE OF IDENTIFICATION AND ESTIMATION OF SOCIOECONOMIC IMPACTS RESULTING FROM PERCETVED RISKS AND CHANGING IMAGES: AN ANNOTATED BIBLIOGRAPHY
}

by

\author{
L.A. Nieves, D.E. Clark, and D. Wernette
}

\begin{abstract}
This annotated bibliography reviews selected literature published through August 1991 on the identification of perceived risks and methods for estimating the economic impacts of risk perception. It updates the literature review found in Argonne National Laboratory report ANL/EAIS/TM-24 (February 1990). Included in this update are (1) a literature review of the risk perception process, of the relationship between risk perception and economic impacts, of economic methods and empirical applications, and of interregional market interactions and adjustments; (2) a working bibliography (that includes the documents abstracted in the 1990 report); (3) a topical index to the abstracts found in both reports; and (4) abstracts of selected articles found in this update.
\end{abstract}

\section{INTRODUCTION}

In 1982 the United States Congress passed the Nuclear Waste Policy Act, which started the process through which a location could be chosen for permanently storing the high-level radioactive waste from the nation's civilian nuclear reactors. The amendments to this act, passed in December of 1987, designated Yucca Mountain in Nevada as the only location to study as a candidate site for such a repository. The original Act and its amendments established a grant mechanism through which the state of Nevada could finance an investigation of the potential socioeconomic impacts that may result from the installation and operation of this facility. Over recent years, the U.S. Department of Energy (DOE) Office of Civilian Radioactive Waste Management (OCRWM or RW) has approved grant requests by the State for performing these studies.

The effects examined by the State researchers have generally been divided into two categories: standard socioeconomic effects and special effects. ${ }^{*}$ Standard effects are defined as the output, employment, infrastructure, and public finance impacts resulting from the

\footnotetext{
"This categorization is explained in the document by Mountain West Research, Inc., An Interim Report on the State of Nevada Socioeconomic Studies, NWPO-SE-022-89, State of Nevada, Nuclear Waste Project Office, Las Vegas, Nev. (June 1989).
} 
construction and operation of the facility. Special effects are the perceptions of risk, image changes, and other phenomena that may result in behavior modification and consequent impacts on the economy.

The identification and estimation of perception-based impacts is a relatively new area of socioeconomic impact assessment. Because development of this area is so recent, much of the literature used as a foundation may be unfamiliar to policymakers. In order to provide a concise guide to this literature, Argonne National Laboratory has prepared this document as an update of a previous annotated bibliography of the most applicable literature. The first bibliography, ANL/EAIS/TM-24, published in 1990 for the Office of Civilian Radioactive Waste Management, was intended to update and enhance a literature review by the Human Affairs Research Center for the Basalt Waste Isolation Project (Liebow et al. 1987), which dealt with the psychological and sociological processes underlying risk perception. Together, these documents review the literature on (1) the process by which perceived risks and images affect behavior and (2) methods for the estimation of the economic impacts from risk perception and image changes.

Section 2 of this report contains an analysis of the material covered in this update plus background material from the previous literature review. This is followed in Section 3 by a comprehensive working bibliography. A topical index, which categorizes the documents by subject matter, is included as Section 4. Finally, Section 5 provides abstracts of key reports and studies. 


\section{SUMMARY AND LITEKATURE REVIEW}

The first portion of this section describes the risk perception process, stigmatization, and the major findings of recent studies funded by the state of Nevada. The theoretical and empirical bases for linking changes in perceived risks to economic impacts are then reviewed. A discussion of the economic methods used in impact evaluation and the relevance of these methods to assessing special effects follows. The final section discusses the use of an integrated interregional framework for analysis of economic impacts.

\subsection{THE RISK PERCEPTION PROCESS}

Risk perception is a process that involves the perceiver, the society and social group of which he is a member, and the perceived object. In this process, the perceiver brings a set of past experiences, learned values, attitudes, expectations, and preferences to the circumstances and context in which a risk is perceived. These experiences, values, etc., often cause the perceiver to focus his attention on some particular characteristics of the risk source, which necessarily diminishes the salience of other characteristics (because individuals can focus on only a limited set of factors at one time). Also complicating the process is the fact that different people employ a variety of cognitive procedures for gathering and processing information about the risk, its source(s), and its potential consequences or meanings. For example, one individual may adopt a fatalistic orientation toward a risk, while another may attempt to gain control by gathering more information or taking some action to reduce its adverse consequences.

The risk perceiver's society or social group is also involved in the risk perception process in a number of ways. A risk is, for the most part, socially determined, as can be seen by the very different orientations of pacifists and National Rifle Association (NRA) members toward guns. Risks are potential threats to valued assets, but what is valued is heavily influenced by the culture or society to which the individual belongs. Finally, psychometric studies suggest that the degree to which a technology is perceived as a source of concern or risk is affected by characteristics of the technology, such as how familiar the public is with it, and how great its potential adverse effects could be. The salience of characteristics of technologies is related to cultural values and assumptions.

Wildavsky and Dake (1990) examined various theories pertaining to the determinants of individual perceptions of risk. They tested the explanatory value of these theories using an existing data set that allowed the development of risk perception measures related to technology, war, social deviance, and the economy. Within this analytical framework, cultural biases are the best predictors of variations in risk perceptions. Those whose world views most support deference to authority or individualism are most tolerant of technological risks, while those with an egalitarian outlook are most risk averse with regard to technology and the environment. These attitudes toward risk taking are not consistent across all types of risks; they vary, for example, when war or social deviance is considered. 


\subsubsection{Stigma}

Stigmatization is the process by which negatively perceived characteristics come to dominate evaluations of a place or individual. This process is exemplified at locations such as Love Canal that are associated with widely publicized incidents of serious contamination. Similarly, peaceful uses of nuclear power have been stigmatized by association with bombs and destruction. The intense negativity of images related to the word "nuclear" has recently been documented by Slovic et al. (1990b). In addition, Slovic et al. (1990a) found that area images are related to preferences for the area as a vacation spot and suggested that the association of nuclear-related images with a location is likely to decrease its desirability. While Slovic et al. (1990a,b) found that nuclear images for Las Vegas or the State of Nevada were associated with lower preferences for the area, persons reporting such images were a small minority.

\subsubsection{State of Nevada Studies}

About a dozen surveys dealing with risk perception and its related impacts have been conducted by researchers funded by the State of Nevada. These studies ranged in scope from national and regional attitudinal surveys to studies of the decision processes of convention planners (Easterling and Kunreuther 1990; Kunreuther et al. 1988b) and corporate decision makers (Mountain West Research 1989a). Flynn et al. (1990) reported that in a 1989 survey of Nevada residents, $70-80 \%$ indicated opposition to repository siting at Yucca Mountain. This opposition was linked with concerns about risks, potential impacts, equity issues, and distrust of the federal government. White et a!. (1990) found that the small communities nearest to the Yucca Mountain site emphasized the potential economic benefits of the repository, while more distant community residents forused on the risks. Overall, this body of research found that perceptions of a high-level nuclear waste repository are intensely negative and that such perceptions have the potential to alter decisions related to activity in any location associated with a repository (Mountain West Research 1989a).

\subsection{RELATIONSHIP BETWEEN RISK PERCEPTION AND ECONOMIC IMPACTS}

This section first provides a theoretical basis for the concept of perceived risk. Studies that directly link changes in risk perception with changes in behavior are also presented. A definition of welfare as used in the economic literature follows, along with a discussion of the basis for impact measurement.

\subsubsection{Perceived Risks}

Virtually every aspect of life has some probability of an ill effect associated with it, which in many cases can be quantified by using statistical techniques. Risk estimates developed by these means have been employed in estimating physical damage functions for 
both technological and natural hazards and have been used in setting safety standards. When it comes to assessing the socioeconomic impacts of an environmental or technological change, however, the technical estimates of risk can be irrelevant, because it is the behavior changes associated with perceived risks that are instrumental in causing impacts.

Economic impacts develop from both actual changes in the environment and from changes perceived by an individual or group. It is the risk perceived by an individual to which he reacts and which guides his consumption decisions. For example, a person who is worried about the risk of carcinogenic contamination of water supplies may consistently purchase bottled drinking water even though technical estimates indicate that such risk is minimal.

Several studies attempted to identify the behavioral responses associated with a particular change in perceived risk. Johnson and Zeigler (1986) documented the role of risk perception in the decision to evacuate during the Three Mile Island incident, in spite of the fact that there was no official evacuation advisory for the general population. Many studies have been conducted to assess people's willingness to live or perform activities at various distances from facilities that present some risk of harm. The findings of Lindell and Earle (1983) and Baker et al. (1977) are typical in that they reported clearly defined gradients of location acceptability with increasing distance from a noxious site. How this type of attitudinal assessment corresponds to behavior was not clear, however. Lindell and Earle, for instance, found that $20 \%$ of a group of non-engineers felt that the minimum acceptable residential distance from a nuclear power plant was greater than 300 miles. Since most nuclear plants are located within 60 miles of a standard metropolitan statistical area (SMSA), it would be interesting to know the group's actual residential choices.

The direct linkage of risk perception to behavior has been investigated in a few studies. Yezer and Rubin (1987) undertook a cross-sectional study of 39 SMSAs in which they examined the effect of changes in the perceived risk of disaster on property values. They found that an increase in disasters over the rate expected from prior experience led to decreases in the housing appreciation rate. In a study that explicitly measured risk perceptions, McClelland et al. (1990) analyzed residential sales data in small neighborhood areas near a landfill that is on the Superfund list. Reiating survey data on perceived risks with home sales prices, they found negative impacts of perceived risks on price levels.

Studies have also examined specifically how the availability of information regarding potential hazards affects behavior. For example, Brookshire et al. (1985) examined the effect of information regarding earthquake risks on housing prices in California. Houses located in "earthquake zones" were found to sell for significantly less than comparable homes outside of such zones. In addition, homes within the zones sold for significantly less after provision of risk information was made mandatory than they did previously, clearly manifesting the impact of altered risk perception. Home values were similarly affected by earthquake and volcanic activity hazard notices in a study by Bernknopf et al. (1990). However, that study found a lack of effect on short-term recreational activity. 
When risks are well documented, perceived and statistically calculated risks may be of the same relative magnitude, though media attention may amplify the perception of some risks. When risks are unknown or controversial, the divergence between perceived risk and statistical risk estimates is likely to be significant. In such cases, it is the public's perception of risk (and not the statistical probability of risk) that is most likely to determine the level of welfare impacts. It is likely that as a risk history develops, the divergence between perceived and statistical risk estimates will decrease. The following section provides a discussion of the translation of perceived risks into welfare impacts.

\subsubsection{Welfare Impacts}

Economists define welfare as an individual's or household's overall level of utility or well-being. All economic analysis assumes that people strive to maximize their welfare by choosing among the goods available to them, given the constraints of their income and the prices and characteristics of the goods. If the price and quality of goods are constant, an increase in income allows people to reach a higher level of welfare. Conversely, if income is constant, an increase in the price or a decrease in the quality of goods results in welfare declines. The changing preferences of individuals are manifested through changes in the market. Consumption of nonmarket goods (goods for which there is no organized mechanism for revealing preferences) affects welfare levels through individual choices regarding residential location, type and place of work, and recreational activity location. Because the introduction of a potentially hazardous facility or activity is commonly viewed as a change in the characteristics of an area, the economic methods used to study environmental goods provide an appropriate basis for evaluating the welfare changes caused by perceived risks.

People choose goods based on their expectations regarding the satisfaction they will receive from that choice; this is generally referred to as the maximization of expected utility. There is an element of risk in most decisions (from marriage to purchasing shoes) that the choice will prove unsatisfactory. Thus, people make decisions on the basis of some implicit probability that the desired outcome will be achieved. When an external event increases the implicit risks associated with a certain item or location after the consumption decision has been made, individuals experience a welfare loss because they are no longer at the utilitymaximizing point previously associated with each good.

Desvousges and Smith (1983) developed a theoretical framewo'k for the evaluation of hazardous waste regulation that explicitly treats perceived risks. They used "statedependent" utility functions to deal with the possibility that people will have different preferences affecting their income allocation if they are facing irreversible consequences than if they are not. A state-dependent utility function has two separate segments, representing different preferences, in which the marginal utility of money may even differ. The relevance of each segment depends on the state of the individual's environment. For example, an individual's preferences for goods and services may be dependent on whether or not a spouse or child survives. This framework can be used to predict risk-reducing behaviors in the face 
of the uncertainty regarding potentially irreversible consequences associated with hazardous wastes.

When people experience a welfare loss due to an environmental change, they will, at the first opportunity, reallocate their income among goods in line with the new set of perceived risks. Thus they will be able to reach a new utility-maximizing position given the altered environmental situation. When the major option open to people to reduce their potential losses is avoidance of a locality considered hazardous, their decisions are likely to impact the local tourism, housing, and labor markets. These are referred to as the primary impacts of the environmental change, and they can be projected by using travel cost, hedonic models, or contingent valuation methods. Secondary market impacts may also be generated through the interaction of these markets with other sectors of the regional economy. Regional economic models are generally useful in estimating the secondary impacts.

When the quality of a consumed good deteriorates in a situation where income is constant, the welfare impacts that occur can be mitigated by increasing income. The effect of compensation in averting avoidance behavior is implied by the Gamble et al. (1978) study of impacts of nuclear power plants on property values. They found higher residential growth rates in the zones closest to the plants, which made large tax payments to local governments, and no evidence of depressed property values. Swartzman et al. (1985) surveyed groups in a rural community considered typical of those selected as hazardous waste disposal sites. They assessed the effects of various types of transfer payments and of various monitoring arrangements designed to reduce perceived risks. Both strategies were effective in doubling acceptance rates for a disposal facility, the compensation slightly more so.

\subsection{ECONOMIC METHODS AND EMPIRICAL APPLICATIONS}

When a change in the environment has decreased an individual's welfare, the magnitude of the loss incurred can be monetarily quantified. Economic analysis does this by asking the question, "What amount of money would it take to get the individual back to his original level of welfare?" In other words, the value of the environmental change is quantified by holding the household welfare level constant.

The approach used in such an evaluation varies depending on who holds the legal rights to the existing state. If the affected individuals have legal rights to the existing state, then the correct measure of welfare loss due to an undesirable environmental change is their willingness to accept (WTA) compensation. This is the amount of money that they feel will offset the costs they will incur and that they will accept to permit the change. If they lack rights to the status quo, the correct measure of potential welfare loss is their willingness to pay (WTP) to prevent the change. The WTP may be thought of as a measure of the benefit of not being affected by the environmental change. Those who are not located at the site of the change also have preferences that are reflected in WTP or WTA measures, though the individual values are generally much smaller than for those closer to the site. If the aggregate WTP for an environmental change is greater than the aggregate WTA, benefits of the change exceed costs and those impacted could be fully compensated. 
The WTP and WTA are typically estimated by using hedonic or contingent valuation methods and approximated by using the travel cost method. An overview of each of these methods and relevant empirical applications are presented in ANL/FAIS/TM-24. In the following section, hedonic methods for measuring and projecting the economic impacts of amenities are discussed in detail. While other methods are relevant to valuing impacts that could result from changes in risk perception, the focus here is on hedonic price analysis, because this is the major area in which recent methodological developments have occurred.

\subsubsection{Hedonic Methods}

Hedonic models are an important tool for valuing environmental goods (or bads) that are not themselves traded in markets. They provide a means of discovering the implicit value that people ascribe to the good in a related market. Since the 1970s, hedonic models have been used to value the impacts of a variety of disamenities on property values. Most hadonic model applications have been to markets for single family residences, though a few studies have also related environmental amenities or disamenities to wage rates (e.g., Herzog and Schlottmann 1990; Hoehn et al. 1987; Roback 1982). Within this framework, perceived risks may be treated as a disamenity that is reflected in home values and wage rates.

The hedonic approach assumes that consumers perceive goods as bundles of attributes and that goods are available with all possible combinations of the attributes. For housing, the relevant attributes include age, number of rooms, air conditioning, fireplaces, neighborhood, and location. Regressing data for these attributes on price reveals the implicit market price of the characteristics. This implicit price may be interpreted as the representative household's WTP for an additional unit of the attribute. Hedonic models have commonly been used to value attributes such as air pollution concentration levels, location in flood or earthquake zones, and proximity to noxious facilities.

The development of a hedonic model for the housing market assumes that households maximize expected utility as a function of housing attributes, including environmental amenities and disamenities, and a composite of all other goods. The household utility function is assumed to be quasi-concave and weakly separable. In nontechnical terms, this implies, among other things, that housing costs are a separate subcategory of the household budget. This utility maximization is subject to a budget constraint in which the price function of the housing attributes is nonlinear. That implies, for example, that the value attached to the number of bathrooms in a house may vary with the total number of rooms.

When a hedonic model is estimated for multiple markets, an inverse demand function for an attribute, such as distance from a waste disposal facilivy, can be derived. In an inverse demand function, the price of the characteristic is defined in terms of the quantity taken. Identification of the inverse demand function is complicated by numerous factors, such as the tendency of exogenous shift variables like income to be highly correlated with some housing attributes. These problems are more readily overcome in multimarket (interregional) analysis (Bartik 1988). 
Hedonic estimation of area amenity and disamenity values recuires the assumption of equilibrium among regional markets when an interregional approach is used. 'The effects of this assumption have been compensated for by the incorporation, by a number of authors, of controls for disequilibrium conditions in the hedonic model. A more refined correction incorporating migration directly in the model is discussed in Section 2.4.2.

\subsubsection{Empirical Applications}

Empirical applications of the hedonic method in which the model specification is not consistent with the theoretical base are numerous. One of the most common errors has been the inclusion of buyer characteristics such as age, race, or education in the price function along with the housing characteristics. In addition, many studies have overlooked the point that since the hedonic model is based on the household budget constraint, the dependent variable should be housing expenditure per time period rather than the sales price. Ideally, detailed cross-sectional, time-series data for both the good and the buyers are needed for multiple markets. It should be noted that if households do not fully perceive the risks associated with a characteristic, the hedonic method will understate willingness to pay for avoidance. In addition, if an area is valued by nonresidents, WTP will be underestimated by the hedonic method because option values are not considered.

Hedonic methods have been found to produce relatively consistent results across locations (Freeman 1979b) in spite of the potential pitfalls in implementation. In the studies reviewed here, no property price effects were measured further than 20 to 25 miles from the hazard investigated. This is partially an artifact of sample design but is consistent with a nonlinear decline in property value impacts as distance from a hazard increases. When impacts of point, rather than area-wide, disamenities have been estimated, effects have generally been significant within a zone of less than five miles radius (Baker 1986; Blomquist 1974; Brookshire et al. 1985; McClelland et al. 1990; Palm 1981; Schmalensee et al. 1975).

Studies of area-wide environmental conditions such as crime rates, earthquake risk, climate, access to recreation opportunities, and number of television stations have found significant price effects. Roback's work (1982) dealing with a variety of both amenities and disamenities is especially important because it examines the relationship between land and latior markets and shows that environmental attributes have simultaneous price impacts in both these markets. Generally, a discmenity will result in both lower property values and

higher wages. Most efforts to estimate economic impacts of risks or disamenities have not addressed this issue.

Some hedonic property value studies have found no negative price effects from proximity to a noxious facility. These include a study that deals with nuclear power plants in the Northeast (Gamble et al. 1978), two Three Mile Island post-accident studies (Gamble and Downing 1981; Nelson 1981), and an analysis of the Fernald, Ohio, Materials Production Center releases of radioactive maısrials (Real Estate Counseling Group of Connecticut, Inc., and Financial Consulting Group of Ohio 1987). In the Northeastern power plant study, Gamble et al. noted that compensation to the local communities may more than offset any 
negative impacts. Compensation expectations may have also affected results in the Three Mile Island and Fernald cases. A flood plain study by MacDonald et al. (1987) provided empirical support for the hypothesis that compensation in excess of losses will increase residential prices in higher flood-risk zones. The lack of identifiable proximity impacts in these studies may result from the effect of compensation expectations, the fact that wage market impacts were not controlled, or measurement error. A threshold or facility density measure may be a more słnsitive indicator of impacts.

Most of the heilonic property value studies which evaluate the impacts of noxious facilities deal with one or a few individual communities (Baker 1986; Blomquist 1974; Gamble and Downing 1981; Grether and Mieszkowski 1980; Harrison and Stock 1984; Kohlhase 1991; McClelland et al. 1990; Michaels and Smith 1990; Nelson 1981; Schmalensee et al. 1975). These studies assume that wages rates are constant within the study area and focus on housing price differentials resulting from proximity of a noxious facility. In general they find that noxious facilities, including power plants and hazardous waste sites, have a depressing effect on property values, with the effect diminishing with distance from the site.

An interregional modeling approach (using data for multiple markets) is characteristic of much of the literature on environmental amenity valuation. This approach controls for the effects of local environment and economic conditions (for both property and labor markets) in evaluating the impacts of noxious facilities. To date only a limited number of studies addressing noxious facility impacts have employed the interregional approach in hedonic analysis. Hoehn et al. (1987) used an interregional framework to develop impact estimates for Superfund sites and waste treatment sites based on property and wage data for 285 SMSAs. This approach provides a basis for generalizing results across locations and shows that, in addition to generating intracity price gradients, noxious facilities affect relative price levels among cities.

Hedonic studies based on wage rates all follow the approach of using large crosssectional samples. The effects on wage rates of injury or fatality rates have been a major focus (Biddle and Zarkin 1988; Brown 1980; Herzog and Schlottmann 1990; Thaler and Rosen 1976). Within these analyses, positive wage differentials for exposure to risks are clearly documented. A few wage rate studies have examined the impacts of disamenities such as the crime rate and air pollution indicators (Clark and Kahn 1989; Gyourko and Tracy 1989; Henderson 1982; Roback 1982, 1988; Smith 1983). These studies have, for the most part, found compensating wage increases associated with exposure to the disamenity.

\subsection{INTERREGIONAL MARKET INTERACTIONS AND ADJUSTMENTS}

Since the 1970s, studies have shown that amenities can influence location choice. The seminal work of Sjaastad (1962) viewed migration decisions as a response to the relative costs and benefits, including amenities, associated with alternative locations. Sjaastad treated migration as an investment decision made to receive a higher return on human capital. More specifically, if the discounted present value of the enhanced earnings were greater than the marginal costs associated with the move, migration was economically 
efficient and was expected to occur. This implies that migration should serve to narrow wage differentials between regions, as workers move from low-wage areas to high-wage areas. In addition, migration should eventually result in a new equilibrium in the labor market where wages are equalized across space. That migration is taking place suggests that the labor market is not currently in equilibrium but is adjusting from a point of disequilibrium, hence the so-called disequilibrium model of migration.

During the 1970s, economists began to recognize that amenities could generate housing value differentials (Harrison and Rubinfeld 1978; Rosen 1974) and wage differentials (Thaler and Rosen 1976). The simultaneous effects of amenities on both markets were recognized during the 1980s (Henderson 1982; Hoehn et al. 1987; Roback 1982). Thus, regional differentials in wages and property values need not be eliminated by migration if they are compensating for amenity differentials. The equilibrium model of migration (put forth by Graves and Linneman [1979]) argued that even if local labor and land markets are in spatial equilibrium, migration can be affected by amenities due to the fact that they are location-specific. That is, as demand for amenities changes with individual income or with stage of the life cycle, migration is required to satisfy that altered demand. This hypothesis was tested by numerous studies including those of Graves (1979, 1980), Schachter and Althaus (1982), and Cushing (1987), with each showing that amenities play an important role in the determination of migration flows.

\subsubsection{Amenities versus Employment as Determinants of Migration}

Greenwood and Hunt (1989) argued that the importance of amenities as a determinant of migration had been overstated and resulted mainly from the failure of Graves (1979) and other authors to consider the role played by employment growth. Specifically, Greenwood and Hunt found that once employment growth in the region is accounted for, amenities do not have nearly the influence on migration that proponents of the equilibrium model suggest. However, most recently, Clark and Cosgrove (1991) found that even after disequilibrium influences are controlled, amenities continue to display important influences on migration behavior.

\subsubsection{Relationship between Migration, Wages, and Property Values}

A general model of the relationship between migration and local input prices (wages and land prices) has yet to be developed. Attempts have been made to consider the theoretical impact of amenities on migration while accounting for that fact that amenities are also reflected in local housing values (Haurin 1980) or wages (Schachter and Althaus 1989). Most recently, Greenwood et al. (1991) empirically estimated a model with migration and interregional wage differentials jointly determined.

Evans (1990) questioned the assumption of equilibrium in models of amenity valuation and migration. Moreover, in the absence of spatial equilibrium, regional wage and housing price differentials do not have the interpretation of WTP for amenity improvement. 
Rather, net in-migration or out-migration will continue until equilibrium is restored, and only then do land or labor price differentials have the interpretation of willingness to pay. A synthesis of the interregional hedonic model with a model of migration is emerging in the literature. The recent paper by Greenwood et al. (1991) derived willingness to pay for an amenity by combining an interregional hedonic wage model with a model of migration. The willingness to pay for the amenity is then defined as that wage premium (for a disamenity) that is required to make the resident indifferent to moving or not moving. This approach avoids the primary weakness of the interregional hedonic model, the assumption of equilibrium. 


\section{WORKING BIBLIOGRAPHY}

Adams, R.C., J.W. Currie, J. Hebert, and R. Shikiar, 1980, Visual Aesthetics Impact of Alternative Closed Cycle Cooling System, U.S. Nuclear Regulatory Commission Report NUREG/CR-0989.

Anderson, R.J., and T, Crocker, 1971, Air Pollution and Residential Property Values, Urban Studies, 8:171-180.

A.postolakis, G., 1990, The Concept of Probability in Safety Assessments of Technological Systems, Science, 250:1359-1364.

Arbel, A., and A. Pizam, 1977, Some Determinants of Urban Hotel Location: The Tourists' Inclinations, Journal of Travel Research, 15(3):18-22.

* Aschenbrenner, K.M., 1978, Single-Peaked Kisk Preferences and Their Dependability on the Gamble's Presentation Mode, Journal of Experimental Psychology, 4(3):513-520.

* Baker, E.J., D.J. Moss, S.G. West, and J.K. Weyant, 1977, Impact of Offshore Nuclear Generating Stations on Recreational Behavior at Acijacent Coastal Sites, U.S. Nuclear Regulatory Commission Report NUREG-0394, prepared for the Office of Nuclear Regulatory Research by Florida Resources and Environmental Analysis Center, Florida State University, Tallahassee, Fla.

* Baker, M.D., 1986, Property Values and Potentially Hazardous Production Facilities: A Case Study of the Kanawha Valley, West Virginia, Ph.D. dissertation, Florida State University, 'Tallahassee, Fla.

* Bar-Hillel, M., 1980, The Base-Rate Fallacy in Probability Judgments, Acta Psychologica, 44:211-233.

Barone, R.N., and A. Wright, 1981, Consumer Perceptions of the Nevada Real Estate Industry, Nevada Review of Business and Economics, spring/summer issue:35-40.

Bartik, T.J., 1988, Measuring the Benefits of Amenity Improvements in Hedonic Price Models, Land Economics, 64(2):172-183.

Beeson, P.E., and R.W. Eberts, 1989, Identifying Productivity and Amenity Effects in Interurban Wage Differentials, Review of Economics and Statistics, 71:443-452.

* Behr, R.L., and S. Iyengar, 1983, Television News, Real-World Cues, and Changes in the Public Agenda, Public Opinion Quarterly, 49:38-57.

\footnotetext{
*Abstract included in ANL $\backslash$ EAIS $\backslash T$ TM-24, Identification and Estimation of Socioeconomic Impacts
} Resulting from Perceived Risks and Changing Images: An. Annotated Bibliography (February 1990). 
** Bernknopf, R.L., D.S. Brookshire, and M.A. Thayer, 1990, Earthquake and Volcano Hazard Notices: An Economic Evaluation of Changes in Risk Perceptions, Journal of Environmental Economics and Management, 18:35-49.

Biddle, J., and G. Zarkin, 1988, Worker Preferences and Market Compensation for Job Risk, Review of Economics and Statistics, 70:660-667.

Bishop, R.C., and T.A. Heberlein, 1979, Measuring Values of Extramarket Goods: Are Indirect Measures Biased?, American Journal of Agricultural Economics, 61:926-930.

Bishop, R. C., T.A. Heberlein, and M.J. Kealy, 1983, Contingent Valuation of Environmental Assets: Comparisons with a Simulated Market, Natural Resources Journal, 23(3):619-633.

Bjornstad, D.J., and D.P. Vogt, 1984, Some Comments Relating to Model Specification on "Effects of Nuclear Power Plants on Residential Property Values," Journal of Regional Science, $24(1): 135-136$.

** Blomquist, G., 1974, The Effect of Electric Utility Power Plart Location on Area Property Value, Land Economics, 50:97-100.

Bockstael, N.E., and K.E. McConnell, 1980, Calculating Equivalent and Compensating Variation for Natural Resource Facilities, Land Economics, 56(1):56-63.

Bord, R.J., and R.E. O'Connor, 1990, Risk Communication, Knowledge, and Attitudes: Explaining Reactions to a Technology Perceived as Risky, Risk Analysis, 10(4):499-506.

** Boyle, M.R., 1989, Assessment of the Impact of a Nuclear Waste Repository at Yucca Mountain on the Economic Development Potential of Las Vegas, Clark County and the Surrounding Area, State of Nevada, Nuclear Waste Project Office, Las Vegas, NWPO-SE016-89.

* Brody, J., 1989, Panhandle Residents' Views of High-Level Nuclear Waste Storage, Texas Department of Agriculture, Austin, Tex.

* Brcokshire, D.S., and T.D. Crocker, 1981, The Advantages of Contingent Valuation Methods for Benefit-Cost Analysis, Public Choice, 36(2):235-252.

* Brookshire, D.S., M.A. Thayer, W.D. Schulze, and R.C. d'Arge, 1982, Valuing Public Goods: A Comparison of Survey and Hedonic Approaches, American Economic Review, 72(1):165-177.

* Brookshire, D.S., M.A. Thayer, J. Tscherhart, and W.. Schulze, 1985, A Test of the Expected Utility Model: Evidence from Earthquake Risks, Journal of Political Economy, 93(2):369-389.

\footnotetext{
"*Abstract included in this document.
} 
Brown, C., 1980, Equalizing Differences in the Labor Market, Quarterly Journal of Economics, 94:113-134.

Brown, J.N., and H.S. Rosen, 1982, On the Estimation of Structural Hedonic Price Models, Econometrica, 50(3):765-768.

Burnell, J.D., 1985, Industrial Land Use, Externalities, and Residential Location, Urban Studies, 22:399-408.

** Burns, W., P. Slovic, R. Kasperson, J. Kasperson, O. Renn, and S. Emani, 1990, Social Amplification of Risk: An Empirical Study, State of Nevada, Nuclear Waste Project Office, Las Vegas, NWPO-SE-027-90, September.

Burt, O.R., and D. Brewer, 1971, Estimation of Net Social Benefits from Outdoor Recreation, Econometrica, 39(5):813-827.

Calantone, R.J., C.A. Di Benedetto, and D. Bojanic, 1987, A Comprehensive Review of the Tourism Forecasting Literature, Journal of Travel Research, 23:28-39.

Calantone, R.J., and J.S. Johar, 1984, Seasonal Segmentation of the Tourism Market Using a Benefit Segmentation Framework, Journal of Travel Research, 23(2):14-24.

Cargill, T.F., and W.R. Eadington, 1978, Nevada's Gaming Revenues: Time Characteristics and Forecasting, Management Science, 24(12):1221-1230.

Carter, E.E., 1972, What Are the Risks In Risk Analysis, Harvard Business Review, JulyAugust.

* Catton, W., 1989, Cargoism and Technology and the Relationship of These Concepts to Important Issues Such as Toxic Waste Disposal Siting, in Psychosocial Effects of Hazardous Toxic Waste Disposal on Communities, D. Peck, ed., C.C. Thomas, Springfield, Ill., pp. 9-117.

Chalmers, J., et al., 1982, Socioeconomic Impacts of Nuclear Generating Stations, prepared by Mountain West Research, Inc. and Social Impact Research, Inc. for the U.S. Nuclear Regulatory Commission, Washington, DC.

Christensen, J.B., S.K. Humphreys, and C. Price, 1985, A Revised Clawson Method: One Part Solution to Multidimensional Disaggregation Problems in Recreation Evaluation, Journal of Environmental Management, 20:333-346.

Clark, D.E., and J.C. Cosgrove, 1990, Hedoric Prices, Identification, and the Demand for Public Safety, Journal of Regional Science, 30(1):105-121.

** Clark, D.E., and J.C. Cosgrove, 1991, Amenities versus Labor Market Opportunities: Choosing the Optimal Distance to Move, Journal of Regional Science, 31(3):311-328. 
Clark, D.E., and J.R. Kahn, 1988, The Social Benefits of Urban Cultural Amenities, Journal of Regional Science, 28(3):363-377.

Clark, D.E., and J.R. Kahn, 1989, The Two-Stage Hedonic Wage Approach: A Methodology for the Valuation of Environmental Amenities, Journal of Environmatial Economics and Management, 16:106-120.

Clark, E.M., and A.J. Van Horn, 1976, Risk-Benefit Analysis and Public Policy: A Bibliography, Energy and Environmental Policy Center, Harvard University, Cambridge, Mass.

Cleary, P.D., and R. Angel, 1984, The Analysis of Relationships Involuing Dichotomous Dependent Variables, Journal of Health and Social Behavior, 25:334-348,

* Cohen, M., J.Y. Jaffray, and T. Said, 1985, Individual Behavior under Risk and under Uncertainty: An Experimental Study, Theory and Decision, 18:203-288.

Cole, G.A., and S.B. Withey, 1981, Perspectives on Risk Perceptions, Risk Analysis, 1(2):143-163.

Commonwealth of Pennsylvania, 1980, The Socio-Economic Impacts of the Three Mile Island Accident: Final Report, Governor's Office of Policy and Planning, Harrisburg, Pa.

Covello, V.T., 1983, The Perception of Technological Risks: A Literature Rentu, Technological Forecasting and Social Change, 23:285-297.

* Covello, V.T., 1987, Decision Analysis and Risk Management Decision Making: Issues and Methods, Risk Analysis, 7(2):131-139.

Crocker, T., 1970, Urban Air Pollution Damage Functions: Theory and Measurement, Riverside Press, University of California.

* Cronin, F.J., 1982, Valuing Nonmarket Goods through Contingent Markets, Pacific Northwest Laboratory Report PNL-4255, Richland, Wash.

Cummings, R.G., D.S. Brookshire, and W.D. Schulze, 1986, Valuing Public Goods: the Contingent Valuation Method, Rowman and Allanheld Publishers, Totowa, N.J.

** Cushing, B.J., 1987, Location-Specific Amenities, Topography, and Population Migration, The Annals of Regional Science, 21(2):74-85.

Dandurand, L., and R. Ralenkotter, 1985, An Investigation of Entertainment Proneness and its Relationship to Gambling Behavior: The Las Vegas Experience, Journal of Travel Research, 23(3):12-16.

* Dardis, R., 1983, Consumer Risk Response and Consumer Protection: An Economic Analysis of Seat Belt Usage, Journal of Consumer Affairs, 17(2):245-261. 
* Dardis, R., G. Davenport, J. Kurin, and J. Marr, 1983, Risk-Benefit Analysis and the Determination of Acceptable Risk, Journal of Consumer Affairs, 17(1):38-56.

** De Boer, C., and I. Catsburg, 1988, The Polls - A Report: The I rnact of Nuclear Accidents on Attitudes toward Nuclear Energy, Public Opinion Quarter', E2(summer):254261.

* Desvousges, W.H., and V.K. Smith, 1983, An Overview: The Benefits of Hazardous Waste Management Regulations, U.S. Environmental Protection Agency, Research Triangle Park, N.C.

DeVany, A.S., 1976, An Economic Model of Airport Noise Pollution in an Urban Environment, in Theory and Measurement of Economic Externalities, S.A.Y. Lin, ed., Academic Press, N.Y., pp. 205-214.

Diggs, D.M., 1988, Risk Communication, Lessons from Natural Hazards: An Annotated Bibliography, Natural Hazards Research and Applications Information Center, Topical Bibliography \#15, University of Colorado, Boulder.

Doderlein, J.M., 1983, Understanding Risk Management, Risk Analysis, 3(1):17-21.

Douglas, M., 1985, Risk Acceptability According to the Social Sciences, Russell Sage Foundation, New York, N.Y.

Eadington, W.R., 1982, The Evolution of Corporate Gambling in Nevada, Nevada Review of Business and Economics, spring issue:13-22.

Earle, T.C., 1981, Public Perceptions of Industrial Risks: The Context of Public Attitudes toward Radioactive Waste, prepared for the Waste Management Systems Studies Program of the Pacific Northwest Laboratory, U.S. Department of Energy.

Earle, T.C., and M.K. Lindell, 1982, Public Perception of Industrial Risks: A Free-Response Approach, BHARC-400/82/017, Battelle Human Affairs Research Centers, Seattle, Wash.

** Easterling, D., and H. Kunreuther, 1990, The Vulnerability of the Convention Industry to the Siting of a High-Level Nuclear Waste Repository, State of Nevada, Nuclear Waste Project Office, Las Vegas, NWPO-SE-031-90, September.

Easterling, D., V. Morwitz, and H. Kunreuther, 1990, Estimating the Economic Impact of a Repository from Scenario-Based Surveys: Models of the Relation of Stated Intent to Actual Behavior, State of Nevada, Nuclear Waste Project Office, Las Vegas, NWPO-SE-035-90.

Edwards, S.F., and G.D. Anderson, 1987, Overlooked Biases in Contingent Valuation Surveys: Some Considerations, Land Economics, 63(2):168-178.

* Edwards, W., and D. von Winterfeldt, 1987, Public Values in Risk Debates, Risk Analysis, 7(2):141-158. 
* Elliott, M.L.P., 1984, Improving Community Acceptance of Hazardous Waste Facilities through Alternative Systems for Mitigating and Managing Risk, Hazardous Waste, 1(3):397410 .

Ellson, R.W., J.W. Mill'man, and R.B. Roberts, 1984, Measuring the Regional Economic Effects of Earthquakes ind Earthquake Predictions, Journal of Regional Science, 24(4):559579.

** Evans, A.W., 1990, The Assumption of Equilibrium in the Analysts of Migration and Interregional Differences: A Review of Some Recent Research, Journal of Regional Science, 30(4):515-532.

* Fesenmaier, D.R., 1985, Modeling Variation in Destination Patronage for Outdoor Recreation Activity, Journal of Travel Research, 23(2):17-23.

* Fields, J.M., and H. Schuman, 1976, Public Beliefs about the Public, Public Opinion Quarterly, 40:427-448.

* Finsterbusch, K., 1989, Community Responses to Exposure to Hazardous Wastes, in Psychosocial Effects of Hazardous Toxic Waste Disposal on Communities, D. Peck, ed., C.C. Thomas, Springfield, Ill., pp. 57-80.

* Fischoff, B., 1979, Informed Consent in Societal Risk-Benefit Decisions, Technological Forecasting and Social Change, 13:347-357.

* Fischoff, B., 1985, Managing Risk Perceptions, Issues in Science and Technology, fall issue:83-96.

** Fischoff, B., P. Slovic, and S. Lichtenstein, 1983, The Public vs. the Experts: Perceived vs. Actual Disagreements about Risks of Nuclear Power, in T'he Analysis of Actual Versus Perceived Risks, Vincent T. Covello, et al., eds., Plenum Press, New York, N.Y., pp. 235-249.

* Fischoff, B., P. Slovic, S. Lichtenstein, S. Read, and B. Combs, 1978, How Safe is Safe Enough? A Psychometric Study of Attitudes towards Technological Risks and Benefits, Policy Sciences, 9:127-152.

* Fischoff, B., S.R. Watson, and C. Hope, 1984, Defining Risk, Policy Sciences, 17:123-139.

Fisher, A.C., and J.V. Krutilla, 1974, Valuing Long Run Ecological Consequences and Irreversibilities, Journal of Environmental Economics and Management, 1:96-108.

FitzSimmons, A., 1987, Have Waste, Will Travel: An Examination of the Implications of HighLevel Nuclear Waste Transportation, Institute of Behavioral Science, University of Colorado, Boulder, Working Paper \#59, July. 
Flynn, C.B., and J.A. Chalmers, 1980, The Social and Economic Effects of the Accldent at Three Mile Island, NUREG/CR-1215, prepared by Mountain West Research, Inc. and Social Impact Research, Inc.

*** Flynn, J.H., P. Slovic, C.K. Mertz, and J. Toma, 1990, Evaluations of Yucca Mountain Survey Findings about the Attitudes, Opinions, and Evaluations of Nuclear Waste Disposal. and Yucca Mountain, Nevada, State of Nevada, Nuclear Waste Project Office, Las Vegas, NWPO-SE-029-90, September.

Follain. J,R., and E. Jimenez, 1985, Estimating the Demand for Housing Characteristics: A Survey and Critique, Regional Science and Urban Economics, 15:77-107.

Folland, S.T., and R.R. Hough, 1991, Nuclear Power Plants and the Value of Agricultural Land, Land Economics, 67(1):30-36.

*** Fox, W.F., H.W. Herzog, and A.M. Schlottmann, 1989, Metropolitan Fiscel Structure and Migration, Journal of Regional Science, 2.9(4):523-536.

Fox, W.F., J.W. Mayo, L.R.T. Hansen, and K.E. Quindry, 1985, An Economic Analysis of a Monitored Retrievable Storage Site for Tennessee: Final Report and Appendices, Center for Business and Economic Research, College of Business Administration, University of Tennessee, Knoxville.

Freeman, A.M., III, 1979a, The Benefits of Environmental Improvement: Theory and Practice, Johns Hopkins University Press, Baltimore, Md., prepared for Resources for the Future.

* Freeman, A.M., III, 1979b, Hedonic Prices, Property Values and Measuring Environmental Benefits: A Survey of the Issues, Scandinavian Journal of Economics, pp. 154-173.

* Freudenburg, W.R., and R.K. Baxter, 1984, Host Community Attitudes toward Nuclear Power Plants: A Reassessment, Social Science Quarterly, 46:1129-1136.

Frey, J.H., 1988, National Telephone Survey on Nuclear Waste Issues, State of Nevada, Nuclear Waste Project Office, August 1.

Friedman, R.S., 1987, Using Consultation and Compensation in Siting Repositories for High. Level Nuclear Waste, Journal of Policy Analysis and Management, 7(1):141-145.

Galster, G.C., 1986, Nuclear Power Plants and Residential Property Values: A Comment on Short-Run us. Long-Run Considerations, Journal of Regional Science, 26(4):803-805.

* Gamble, H.B., and R.H. Downing, 1981, Effects of the Accident at Three Mile Island on Residential Property Values and Sales, NUREG/CR-2063, prepared by The Institute for Research on Land and Water Resources, Pennsylvania State University, April.

Gamble, H.B., and R.H. Downing, 1982, The Effects of Nuclear Power Plants on Residential Property Values, Journal of Regional Science, 22(4):457-478. 
* Gamble, H.B., R.H. Downing, and O.H. Sauerlender, 1978, Effects of Nuclear Power Plants on Community Growth and Residential Property Values, NUREG/CR-0454, U.S, Nuclear Regulatory Commission, Washington, D.C.

* Gardner, G.T., A. Tiemann, L. Gould, D. DeLuca, L. Doob, and J. Stolwijk, 1982, Risk and Benefit Perceptions, Acceptability Judgments, and Self-Reported Actions toward Nuclear Power, Journal of Social Psychology, 116:179-197.

Getz, M., and Y. Huang, 1977, Consumer Revealed Preference for Environmental Goods, Review of Economics and Statistics, 60:449-458.

* Giannici, B., and M. Galluzzo, 1983, Socially Acceptable Level of Risk: Some Quantitative Considerations, Reliability Engineering, 5:37-45.

* Gill, D., and S. Picou, 1989, Toxic Waste Disposal Sites as Technological Disasters, in Psychosocial Effects of Hazardous Toxic Waste Disposal on Communities, D. Peck, ed., C.C. Thomas, Springfield, Ill., pp. 81-97.

Golant, S., and I. Burton, 1969, Avoidance-response to the Risk Environment, Natural Hazard Research series, Working Paper No. 6., University of Toronto, Ontario, Canada.

* Goldhaber, M.K., P.S. Houts, and R. DiSabella, 1983, Moving after the Crisis: A Prospective Study of Three Mile Island Population Mobility, Environment and Behavior, 15(1):93-120.

Gould, L.C., 1982, Risk and Benefit Perceptions, Acceptability Judgments, and Self-Reported Actions toward Nuclear Power, Jaurnal of Social Psychology, 116:179-197.

** Graves, P.E., 1979, A Life-Cycle Empirical Analysis of Migration and Climate, by Race, Journal of Urban Economics, 6:135-147.

** Graves, P.E., 1980, Migration and Climate, Journal of Regional Science, 20(2):227-237.

Graves, P.E., 1983, Migration with a Composite Amenity: The Role of Rents, Journal of Regional Science, 24(4):541-546.

** Graves, P.E., and P.D. Linneman, 1979, Household Migration: Theoretical and Empirical Results, Journal of Urban Economics, 6:383-404.

** Graves, P.E., R.L. Sexton, and T.A. Knapp, 1984, A Multi-Disciplinary Interpretation of Migration: Amenity Capitalization in Both Land and Labor Markets, Annals of Regional Science, 18(2):35-44.

Greenberg, M., et al., 1986, Local Planning "s. National Policy: Urban Growth Near Nuclear Power Stations in the United States, Town Planning Review, 57:225-237.

** Greenwood, M.J., and G.L. Hunt, 1989, Jobs versus Amenities in the Analysis of Metropolitan Migration, Journal of Urban Economics, 25(1):1.16. 
*:* Greenwnod, M.J., G.L. Hunt, D.S. Rickman, and G.I. Treyz, 1991, Migration, Regional Equilibrium, and the Estimation of Compensating Differentials, American Economic Review, 81(5):1382-1390.

* Grogory, R., and S. Lichtenstein, 1987, A Review of the High-Level Nuclear Waste Repository Siting Analysis, Risk Analysis, 7(2):219-223.

* Grether, D.M., and P. Mieszkowski, 1980, The Effects of Nonresidential Land Uses on the Prices of Adjacent Housing: Some Estimates of Proximity Effects, Journal of Urban Economics, $8: 1-15$.

Gyourko, J., and J. Tracy, 1989, The Importance of Local Fiscal Conditions in Analyzing Local Labor Markets, Journal of Political Economy, 97(5):1208-1231.

*** Hadden, S.G., 1991, Public Perception of Hazardous Waste, Risk Analysis, 11(1):47-57.

Hageman, R.K., 1981, Nuclear Waste Disposal: Potentia! Property Value Impacts, Natural Resources Journal, 21:789-810.

* Hallman, W., and A. Wandersman, 1989, Perception of Risk and Toxic Hazards, in Psychosocial Effects of Hazardous Toxic Waste Disposal on Communities, D. Peck, ed., C.C. Thomas, Springfield, Ill., pp. 31-55.

Halvorsen, R., and H.O. Pollakowski, 1981, Choice of Functional Form for Hedonic Price Equations, Journal of Urban Economics, 10:37-49.

Hanson, S., J.D. Vitek, and P.O. Hanson, 1979, Natural Disaster: Long-Range Impact on Human Response to Future Disaster Threats, Environment and Behavior, 11(2):268-284.

* Harding, C.M., and J.R. Eiser, 1984, Characterizing the Perceived Risks and Benefits of Some Health Issues, Risk Analysis, 4(2):131-141.

Harrison, D., Jr., and D.L. Rubinfeld, 1978, Hedonic Housing Prices and the Demand for Clean Air, Journal of Environmental Economics and Management, 5:81-102.

* Harrison, D., Jr., and J.H. Stock, 1984, Hedonic Housing Values, Local Public Goods, and Benefits of Hazardous Waste Cleanup, Kennedy School of Government, Harvard University, Cambridge, Mass., November.

Haspel, A.E., and F.R. Johnson, 1982, Multiple Destination Trip Bias in Recreation Benefit Estimation, Land Economics, 58:364-372.

Haurin, D.R., 1980, The Regional Distribution of Population, Migration, and Climate, Quarterly Journal of Economics, 95:293-308.

Hawes, D.K., 1977, Psychographics Are Meaningful . . . Not Merely Interesting, Journal of Travel Research, 15(4):1-7. 
* Hawkes, G.R., M. Pilisuk, M.C. Stiles, and C. Acredolo, 1984, Assessing Rish: A Public Analysis of the Medfly Eradication Program, Public Opinion Quarterly, 48:443-451.

*** Henderson, J.V., 1982, Evaluating Consumer Amenities and Interregional Welfare Differences, Journal of Urban Echnomics, 11(1):32-59.

** Herzog, H., and A. Schlottmann, 1990, Valuing Risk in the Workplace: Market Price, Willingness to Pay, and the Optimal Provision of Safety, Review of Economics and Statistics, $72(3): 463-470$.

Hickey, C.R., Jr., 1981, Impact of the 1979 Accident at Three Mile Island Nuclear Station on Recreational Fishing in the Siusquehanna River, NUREG-0754, U.S. Nuclear Regulatory Commission, Office of Nuclear Reactor Regulation, Washington, D.C., March.

Hively, W., 1988, Nuclear Power at Risk, American Scientist, 76:341-343.

** Hoehn, J.P., M.C. Berger, and G.C. Blomquist, 1987, A Hedonic Model of Interregional Wages, Rents, and Amenity, Values, Journal of Regional Science, 27(4):605-620.

* Hohenemser, C., R. Kasperson, and R. Kates, 1977, The Distrust of Nuclear Power, Science, 191:25-33.

Houts, P.S., and M.K. Goldhaber, 1981, Psychological and Social Effects on the Population Surrounding Three Mile Island after the Nuclear Accident on March 28, 1979, Energy, Environment and the Economy, Pennsylvania Academy of Sciences, pp. 151-164.

* Hughey, J.B., J.W. Lounsbury, E. Sundstrom, and T.J. Mattingly, Jr., 1983, Changing Expectations: a Longitudinal Study of Community Attitudes toward a Nuclear Power Plant, American Journal of Community Psychology, 11(6):655-672.

Hunt, J.D., 1975, Image as a Factor in Tourism Development, Journal of Travel Research, 13(3):1-7.

Izraeli, O., 1987, The Effect of Environmental Attributes on Earnings and Housing Values Across SMSA's, Journal of Urban Economics, 22:361-376.

Jackson, E.L., 1981, Response to Earthquake Hazard: The West Coast of North America, Environment and Behavior, 13(4):387-416.

* Johnson, E.J., and A. Tversky, 1984, Representations of Perceptions of Risks, Journal of Experimental Psychology, 113(1):55-70.

* Johnson, J.H., and D.J. Zeigler, 1986, Modelling Evacuation Behavior During the Three Mile Island Reactor Crisis, Socio-Economic Planning and Science, 20:165-171.

Johnson, R.L., and D.B. Suits, 1983, A Statistical Analysis of the Demand for Visits to U.S. National Parks: Travel Costs and Seasonality, Journal of Travel Research, 22:21-24. 
* Kahneman, D., and A. Tversky, 1979, Prospect Theory: An Analysis of Decision under Risk, Econometrica, 47(2):263-291.

* Kahneman, D., and A. Tversky, 1984, Choices, Values, and Frames, American Psychologist, 39(4):341-350.

* Kasperson, R.E., 1983, Acceptability of Human Risk, Environmental Health Perspectives, 52:15-20.

* Kasperson, R.E., G. Berk, D. Pijawka, A.B. Sharaf, and J. Wood, 1980, Public Opposition to Nuclear Energy: Retrospect and Prospect, Science, Technology and Human Values, 5(31):11-23.

** Kasperson, R.E., O. Renn, P. Slovic, H.S. Brown, J. Emel, R. Goble, J.X. Kasperson, and S. Ratick, 1988, The Social Amplification of Risk: A Conceptual Framework, Risk Analysis, $8(2): 177-187$.

** Kiecolt, K.J., and J.M. Nigg, 1982, Mobility and Perceptions of a Hazardous Environment, Environment and Behavior, 14(2):131-154.

Knapp, T.A., and P.E. Graves, 1989, On the Role of Amenities in Models of Migration and Regional Development, Journal of Regional Science, 29(1):71-87.

** Kohlhase, J., 1991, The Impact of Toxic Waste Sites on Housing Values, Journal of Urban Economics, 30:1-26.

Kraus, N.N., and P. Slovic, 1988, Taxonomic Analysis of Perceived Risk: Modeling Individual and Group Perceptions within Homogeneous Hazard Domains, Risk Analysis, 8(3):435-455.

Krauskopf, K., 1990, Disposal of High-Level Nuclear Waste: Is It Possible?, Science, 249:1231-1232.

Krawiec, F., 1980, Economic Measurement of Environmental Damages, Solar Energy Research Institute, Boulder, Colo., May.

** Kunreuther, H., W. Desvousges, and P. Slovic, 1988a, Nevada's Predicament: Public Perceptions of Risk from the Proposed Nuclear Waste Repository, Environment, 30(8):16-33.

** Kunreuther, H., D. Easterling, W. Desvousges, and P. Slovic, 1990, Public Attitudes toward Siting a High-Level Nuclear Waste Repository in Nevada, Risk Analysis, 10(4):459-484.

Kunreuther, H., D. Easterling, and P. Kleindorfer, 1988b, The Convention Planning Process: Potential Impact of a High-Level Nuclear Waste Repository in Nevada, State of Nevada, Nuclear Waste Project Office, Las Vegas, NWPO-SE-021-90, September. 
Kunreuther, H., and P.R. Kleindorfer, 1988, A Sealed-Bid Auction Mechanism for Siting Noxious Facilities, American Economic Review, Papers and Proceedings, 76(2):295-299.

** Kunreuther, H., and P. Slovic, 1989, Forecasting the Adverse Economic Consequences of a Nuclear Waste Repository in Nevada, presented at the AAAS Annual Meeting, San Francisco, Calif.

Las Vegas Convention and Visitors Authority, 1988, Marketing Bulletin: 1987 Summary, 15(64), March.

Liebow, E.B., J.A. Fawcett-Long, and E.S. Terrill, 1987, Understanding Socioeconomic Aspects of Risk Perception: Progress Report FY-1987, Working Draft, prepared for the U.S. Department of Energy by Battelle Human Affairs Research Centers, Seattle, Wash., November.

* Lindell, M.K., and T.C. Earle, 1983, How Close Is Close Enough: Public Perceptions of the Risks of Industrial Facilities, Risk Analysis, 3(4):245-253.

Lindell, M.K., and R.W. Perry, 1990, Effects of the Chernobyl Accident on Public Perceptions of Nuclear Plant Accident Risks, Risk Analysis, 10(3):393-399.

Little, R., and R. Krannich, 1990, Major Sociocultural Impacts of the Yucca Mountain HighLevel Nuclear Waste Repository on Nearby Rural Communities, State of Nevada, Nuclear Waste Project Office, Las Vegas, NWPO-SE-033-90, September.

* Lopes, L.L., 1983, Observations, Journal of Experimental Psychology, 9(1):137-144.

* MacDonald, D.N., J.C. Murdoch, and H.L. White, 1987, Uncertain Hazards, Insurance, and Consumer Choice: Evidence from Housing Markets, Land Economics, 63(4):361-371.

** McClelland, G.H., W.D. Schulze, and B. Hurd, 1990, The Effect of Risk Beliefs on Property Values: A Case Study of a Hazardous Waste Site, Risk Analysis, 10(4):485-497.

McDaniels, T.L., 1988, Chernobyl's Effects on the Perceived Risks of Nuclear Power: A Small Sample Test, Risk Analysis, 8(3):457-461.

McMillan, M.L., B.G. Reid, and D.W. Gillen, 1980, An Extension of the Hedonic Approach for Estimating the Value of Quiet, Land Economics, 56(3):315-328.

** Maderthaner, R., P. Pahner, G. Guttmann, and H.J. Otway, 1976, Perception of Technological Risks: The Effect of Confrontation, International Institute for Applied Systems Analysis, Laxenburg, Austria, Research Memorandurn RM-76-53, June.

Majid, I., J.A. Sinden, and A. Randall, 1983, Benefit Evaluation of Increments to Existing Systems of Public Facilities, Land Economics, 59(4):377-392. 
* Malamud, B., 1973, Gravity Model Calibration of Tourist Travel to Las Vegas, Journal of Leisure Research, 5(fall):23-33.

* Manning, D.T., 1982, Post-TMI Perceived Risk from Nuclear Power in Three Communities, Nuclear Safety, 23(4):379-384.

Marston, S.A., 1984, A Political Economy Approach to Hazards: A Case Study of California Lenders and the Earthquake Threat, Department of Geography, Üniversity of Colorado, Boulder, Colo., Working Paper \#49, February.

Mayo, E., 1975, Tourism and the National Parks: A Psychographic and Attitudinal Study, Journal of Travel Research, 14(1):14-18.

* Mazur, A., 1989, Communicating Risk in the Mass Media, in Psychosocial Effects of Hazardous Toxic Waste Disposal on Communities, D. Peck, ed., C.C. Thomas, Springfield, Ill., pp. 119-137.

** Mazur, A., and G.S. Hall, 1990, Effects of Social Influence anả Measured Exposure Level on Response to Radon, Sociological Inquiry, 60(3):274-284.

** Michaels, G., and V.K. Smith, 1990, Market Segmentation and Valuing Amenities with Hedonic Models: The Case of Hazardous Waste Sites, Journal of Urban Economics, 28:223-242.

Mieszkowski, P., and A.M. Saper, 1978, An Estimate of the Effects of Airport Noise on Property Values, Journal of Urban Economics, 5:425-440.

** Mitchell, R., 1980, Public Opinion and Nuclear Power before and after Three Mile Island, Resources, 64(Jan.-Apr.):5-8.

Mitchell, R.C., and R.T. Carson, 1986, Property Rights, Protest, and the Siting of Hazardous Waste Facilities, American Economic Review, Papers and Proceedings, 76(2):285-290.

Morell, D., and C. Magorian, 1982, Siting Hazardous Waste Facilities: Local Opposition and the Myth of Preemption, Ballinger Publishing Co., Cambridge, Mass.

Morgan, M.G., M. Henrion, S.C. Morris, and D.A.L. Amaral, 1985, Uncertainty in Risk Assessment, Environmental Science Technology, 19(8):662-667.

Mountain West Research, 1989a, Yucca Mountain Socioeconomic Project: An Interim Report on the State of Nevada Socioeconomic Studies, State of Nevada, Nuclear Waste Project Office, Las Vegas, NWPO-SE-022-89, June.

Mountain West Research, 1989b, Yucca Mountain Socioeconomic Project Preliminary Findings: 1989 Nevada State Telephone Survey, State of Nevada, Nuclear Waste Project Office, Las Vegas, NWPO-SE-025-89, June. 
Muellbauer, J., 1974, Household Production Theory, Quality, and the "Hedonio Technique," American Economic Review, $\operatorname{LXIV(6):977-994.~}$

Murdock, S.H., and F.L. Leistritz, 1983, Methods for Assessing the Socioeconomic Impacts of Large-Scale Resource Developments, Texas A \& M University, College Station, Tex., March.

Mushkatel, A.H., K.D. Pijawka, and M. Dantico, 1990, Risk-Induced Social Impacts: the Effects of the Proposed Nuclear Waste Repository on Residents of the Las Vegas Metropolitan Area, State of Nevada, Nuclear Waste Project Office, Las Vegas, NWPO-SE-032-90, September.

* Nelkin, D., 1981, Nuclear Power as a Feminist Issue, Environment, 23:15-39.

Nelson, J.P.y 1978, Residential Choice, Hedonic Prices, and the Demand for Air Quality, Journal of Urban Economics, 5:357-369.

Nelson, J.P., 1979, Airport Noise, Location Rent and the Market for Residential Amenities, Journal of Envirunmental Economics and Management, 6:320-331.

Nelson, J.P., 1980, Airports and Property Values: A Survey of Recent Evidence, Journal of Transportation Economics and Policy, 14:37-52.

* Nelson, J.P., 1981, Three Mile Island and Residential Property Values: Empirical Analysis and Policy Implications, Land Economics, 57(3):363-372.

* Palm, R., 1981, Real Estate Agents and Special Studies Zones Disclosure: The Response of California Home Buyers to Earthquake Hazards Information, Institute of Behavioral Science, University of Colorado, Boulder.

Panel on Social and Economic Aspects of Radioactive Waste Management, 1984, Social and Economic Aspects of Radioactive Waste Disposal, National Academy Press, Washington, D.C.

* Park, W.M., and W.L. Miller, 1982, Flood Risk Perceptions and Overdevelopment in the Floodplain, Water Resources Bulletin, 18(1):89-94.

* Payne, B.A., S.J. Olshansky, and T.E. Segel, 1987, The Effects on Property Values of Proximity to a Site Contaminated with Radioactive Waste, Natural Resources Journal, 27(summer):579-590.

Peelle, E., 1980, Social Impact Mitigation and Nuclear Waste Repository Siting, DOE/TIC11260, prepared for the Office of Nuclear Waste Isolation, U.S. Department of Energy, Washington, D.C.

** Planning Information Corporation, 1988, Retirement Migration and Military Retirement, State of Nevada, Nuclear Waste Project Office, Las Vegas, NWPO-SE-001-88, June. 
*:* Popper, F.J., 1983, LP/HC and LULUs: The Political Uses of Risk Analysis in Land.Use Planning, Risk Analysis, 3(4):255-263.

* Portney, K.E., 1984, Allaying the NIMBY Syndrome: The Potential for Compensation in Hazardous Waste Treatment Facility Siting, Hazardous Waste, 1(3):411-421.

Price, C., J.B. Christian, and S.K. Humphreys, 1986, Elasticities of Demand for Recreation Site and for Recreation Experience, Environment and Planning, 18:1259-1263.

* Randall, A., J.P. Hoehn, and D.S. Brookshire, 1983, Contingent Valuation Surveys for Evaluating Environmental Assets, Natural Resources Journal, 23(3):635-648.

Randall, A., B. Ives, and C. Eastman, 1974, Bidding Games for Valuation of Aesthetic Environmental Improvements, Journal of Environmental Economics and Management, 1:132-149.

Randall, A., and J.R. Stoll, 1980, Consumer's Surplus in Commodity Space, American Economic Review, 70(3):449-455.

* Real Estate Counseling Group of Connecticut, Inc. and Financial Consulting Group of Ohio, 1987, Patterns of Real Estate Market Behavior around the Feed Materials Production Center Fernald, Ohio, Volume I.

Real Estate Counseling Group of Connecticut, Inc. and Financial Consulting Group of Ohio, 1989, Patterns of Real Estate Market Behavior around the Feed Materials Production Center Fernald, Ohio, Volume II.

Ridker, R.G., and J.A. Henning, 1967, The Determinants of Residential Property Values with Special Reference to Air Pollution, Review of Economics and Statistics, XLIV(2):246-257.

* Roback, J., 1982, Wages, Rents, and the Quality of Life, Journal of Political Economy, 90(6):1257-1278.

Roback, J., 1988, Wages, Rents, and Amenities: Differences among Workers and Regions, Economic Inquiry, 26:23-41.

Rosen, S., 1974, Hedonic Prices and Implicit Markets: Product Differentiation in Pure Competition, Journal of Political Economy, 82:34-55.

** Schachter, J., and P.G. Althaus, 1982, Neighborhood Quality and Climate as Factors in U.S. Net Migration Patterns, 1974-1976, American Journal of Economics and Sociology, 41(4):387-400.

** Schachter, J., and P.G. Althaus, 1989, An Equilibrium Model of Gross Migration, Journal of Regional Science, 29(2):143-160. 
Schlottmann, A.M., and H.W. Herzog, 1984, Career and Geographic Mobility Interactions: Implications for the Age Selectivity of Migration, Journal of Human Resources, 19(winter):72-86.

* Schmalensee, R., R. Ramanathan, W. Ramm, and D. Smallwood, 1975, Measuring External Effects of Solid Waste Management, U.S. Environmental Protection Agency Report EPA-600/575-010, March.

* Schneider, W., 1986, Opinion Outlook, National Journal, June 21 issue:1562-1563.

Schulze, W.D., R.A. d'Arge, and D.S. Brookshire, 1981, Valuing Environmental Commodities: Some Recent Experiments, Land Economics, 57(2):151-172.

Sekiguchi, H.S., and E.A. Zane, 1981, The Current Structure of the Nevada Real Estate Industry, Nevada Review of Business and Economics, spring/summer issue:30-34.

* Seller, C., J.R. Stoll, and J.P. Chavas, 1985, Validation of Empirical Measures of Welfare Change: A Comparison of Nonmarket Techniques, Land Economics, 61(2):156-175.

* Shakow, D., and R. Goble, 1982, Technological Risk Perception and Nuclear Power Costs, Technological Forecasting and Social Change, 21:185-199.

Short, J.F., Jr., 1984, The Social Fabric at Risk: Toward the Social Transformation of Risk Analysis, American Sociological Review, 49:711-725.

Sigmon, E.B., 1987, Achieving a Negotiated Compensation in Siting: The MRS Case, Journal of Policy Analysis and Management, 6(2):170-179.

** Sjaastad, L.A., 1962, The Costs and Returns of Human Migration, Journal of Political Economy, 70(5):80-93.

* Skaburskis, A., 1989, Impact Atienuation in Nonconflict Situations: The Price Effects of a Nuisance Land-Use, Environment and Planning, 21:185-199.

Slovic, P., 1987, Forecasting the Adverse Economic Effects of a Nuclear Waste Repository, Waste Management '87: Proceedings of the Symposium on Waste Management held in Tucson, Arizona, University of Arizona Press, Tucson.

* Slovic, P., 1987, Perception of Risk, Science, 236:280-285.

*:: Slovic P., B. Fischoff, and S. Lichtenstein, 1981, Perception and Acceptability of Risk from Energy Systems, Advances in Environmental Psychology, 3:155-170.

** Slovic, P., M. Layman, and J.H. Flynn, 1990a. Images of a Place and Vacation Preferences: Implications of the 1989 Surveys for Assessing the Economic Impacts of a Nuclear Waste Repository in Nevada, State of Nevada, Nuclear Waste Project Office, Las Vegas, NWPO-SE030-90, November. 
Slovic, P., M. Layman, and J.H. Flynn, 1990b, What Comes to Mind When You Hear the Words "Nuclear Waste Repository?" A Study of 10,000 Images, State of Nevada, Nuclear Waste Project Office, Las Vegas, NWPO-SE-028-90, September.

Slovic, P., M. Layman, and J.H. Flynn, 1991, Lessons from Yucca Mountain, Environment, 33(3):7-30.

** Slovic, P., M. Layman, N. Kraus, J. Chalmers, G. Gesell, and J. Flynn, 1989, Perceived Risk, Stigma, and Potential Economic Impacts of a High-Level Nuclear Waste Repository in Nevada, State of Nevada, Nuclear Waste Project Office, Las Vegas, NWPO-SE-023-89, July.

Slovic, P., S. Lichtenstein, and B. Fischoff, 1979, Intages of Disaster: Perception and Acceptance of Risks from Nuclear Power, in Energy Risk Management, G. Goodman and W. Rowe, eds., Academic Press, London, pp. 34-55.

Smeral, E., 1988, Tourism Demand, Economic Theory and Econometrics: An Integrated Approach, Journal of Travel Research, 26(spring):38-43.

Smith, V.K., 1983, The Role of Site and Job Characteristics in Hedonic Wage Models, Journal of Urban Economics, 13:296-321.

Smith, V.K., 1986, Benefit Analysis for Natural Hazards, Risk Analysis, 6(3):325-334.

* Smith, V.K., and W.H. Desvousges, 1986a, Asymmetries in the Valuation of Risk and the Siting of Hazardous Waste Disposal Facilities, American Economic Review, Papers and Proceedings, 76(2):291-294.

* Smith, V.K., and W.H. Desvousges, 1986b, The Value of Avoiding a 'Lulu': Hazardous Waste Disposal Sites, Review of Economics and Statistics, LXVIII(2):293-299.

Smith, V.K., and W.H. Desvousges, 1987, An Empirical Analysis of the Economic Value of Risk Changes, Journal of Political Economy, 95(1):89-113.

Smith, V.K., W.H. Desvousges, and M.P. McGivney, 1983, Estimating Water Quality Benefits: An Econometric Analysis, Southern Economic Journal, 50(1):422-437.

Stroup, R.L., and D.R. Leal, 1989, Dealing with the NIMBY Syndrome, Working Paper 89-8, Political Economy Research Center, Bozeman, Mont.

Swartz, D.G., and I.E. Strand, Jr., 1981, Avoidance Costs Associated with Imperfect Information: The Case of Kepone, Land Economics, 57(2):139-150.

* Swartzman, D., K. Croke, and S. Swibel, 1985, Reducing Aversion to Living near Hazardous Waste Facilities through Compensation and Risk Reduction, Journal of Environmental Management, 20:43-50. 
Thaler, R., and S. Rosen, 1976, The Value of Saving a Life: Evidence from the Labor Market, in Household Production and Consumption, N.E. Terleckyj, ed., Columbia University Press, New York, N.Y., pp. 265-298.

Thomas, K., 1981, Comparative Risk Perception: How the Public Perceives the Risks and Benefits of Energy Systems, in The Assessment and Perception of Risk, F. Warner and D.H. Slater, eds., The Royal Society, London, England, pp. 35-50.

Trunk, A.D., and E.V. Trunk, 1983, Impact of the Three Mile Island Accident as Perceived by Those Living in the Surrounding Community, in The Analysis of Actual Versus Perceived Risks, Vincent T. Covello et al., eds., Plenum Press, New York, N.Y., pp. 225-233.

Tversky, A., and D. Kahneman, 1974, Judgment under Uncertainty: Heuristics and Biases, Science, 185:1124-1131.

* Tversky, A., and D. Kahneman, 1981, The Framing of Decisions and the Psychology of Choice, Science, 185:453-458.

University of Tennessee, 1985, An Economic Analysis of a Monitored Retrievable Storage Site for Tennessee, Center for Business and Economic Research, College of Business Administration, Knoxville, Tenn., December 17.

* Uysal, M., and J.L. Crompton, 1985, An Overview of Approaches Used to Forecast Tourism Demand, Journal of Travel Research, 23(4):7-15.

Vari, A., R. Kemp, and J.L. Mumpower, 1991, Public Concerns about LLRW Facility Siting: A Comparative Study, Journal of Cross-Cultural Psychology, 22(1):83-102.

Viscusi, W.K., and W.A. Magat, with J. Huber et al., 1987, Corsumer and Worker Responses to Hazard Information, Harvard University Press, Cambridge, Mass.

* Wallsten, T.S., and D.V. Budescu, 1983, Encoding Subjective Probabilities: A Psychological and Psychometric Review, Management Science, 29(2):151-173.

* Weinrich, P., 1986, Expected Utility and Risk, British Journal of Philosophical Science, 37:419-442.

White, A.D., H.J. Sumka, and H. Erekson, 1979, An Estimate of a Structural Hedonic Price Model of the Housing Market: An Application of Rosen's Theory of Implicit Markets, Econometrica, 47(5):1151-1173.

White, A.L., S. Edwards, and S. Emani, 1990, Risk Perceptions of the Yucca Mountain Repository: A Comparative Assessment of Caliente and Other Southern Nevada Communities, Center for Technology, Environment and Development, Clark University, Worcester, Mass.

White, A.L., and S.J. Ratick, 1989, Risk, Compensation, and Regional Equity in Locating Hazardous Facilities, Papers of the Regional Science Association, 67:29-42. 
** Wildavsky, A., and K. Dake, 1990, Theories of Risk Perception: Who Fears What and Why? ? Daedalus, fall issue:41-60.

* Willard, D.E., and M.M. Swenson, 1984, Why Not in Your Backyard? Scientific Data and Nonrational Decisions about Risk, Environmental Management, 8(2):93-100.

* Yezer, A.M., and C.B. Rubin, 1987, The Local Economic Effects of Natural Disasters, Institute of Behavioral Science, Working Paper No. 61, University of Colorado, Boulder, Colo. 


\section{TOPICAL INDEX TO ABSTRACTS}

\section{CONTINGENT VALUATION}

* Brookshire and Crocker 1981

* Brookshire et al. 1982

* Cronin 1982

* Desvousges and Smith 1983

* Randall et al. 1983

* Seller et al. 1985

* Smith and Desvousges 1986a

\section{ENVIRONMENTAL (DIS)AMENITIES}

* Baker et al. 1977

* Baker 1986

Bernknopf et al. 1990

Blomquist 1974

* Brookshire et al. 1982

* Brookshire et al. 1.985

Clark and Cosgrove 1991

* Cronin 1982

Cushing 1987

Evans 1990

F'ox et al. 1989

* Freeman 1979

* Gamble and Downing 1981

* Gamble et al. 1978

* Goldhaber et al. 1983

Graves 1979

Graves 1980

Graves and Linneman 1979

Graves et al. 1984

Greenwood and Hunt 1989

Greenwood et al. 1991

Henderson 1982

Hoehn et al. 1987

Kiecolt and Nigg 1982

Kohlhase 1991

* Lindell and Earle 1983

* MacDonald et al. 1987

Michaels and Smith 1990

* Abstract included in ANL/EAIS/TM-24, Identification and Estimation of Socioceonomic: Impacts. Resulting from Perceived Risks and Changing Images: An Annotated Bibliography (Fobruary 1.990). 
* Nelson 1981

* Palm 1981

Popper 1983

" Real Esstate Counseling Group of Connecticut 1987

* Roback 1982

Schachter and Althaus 1982

Schachter and Althaus 1989

* Schmalenseo et al. 1975

Slovic et al. 1990a

* Smith and Desvousges 1986a

* Smith and Deswousges 1986b

* Yezer and Rubin 1987

\section{ECONOMIC DEVELOPMENT}

Boyle 1989

\section{HAZARDOUS WASTE}

* Brody 1989

* Catton 1989

* Desvousges and Smith 1983

* Elliott 1984

* Finsterbusch 1989

* Gill and Picou 1989

* Gregory and Lichtenstein 1987

Hadden 1991

* Harrison and Stock 1984

Hoehn et al. 1987

Kohlhase 1991

* Lindell and Earle 1983

McClelland et al. 1990

* Mazur 1989

Michaels and Smith 1990

* Payne et al. 1987

Popper 1983

* Portney 1984

* Smith and Desvousges 1986a

* Smith and Desvousges 1986b

* Swartzman et al. 1985

* Willard and Swenson 1984

\section{HEDONIC METHODS}

* Baker 1986

Blomquist 1974

* Brookshire et al. 1982 
14 Brookshire at al, 1985

" Desvousges and Smith 1983

* Freeman 1979

* Gamble and Downing 1981

* Gamble et al. 1978

* Grether and Mieszkowski 1980

* Harrison and Stock 1984 Herzog and Schlottmann 1990 Hoehn et al. 1987 Kohlhase 1991

* MacDonald et al, 1987 Michaels and Smith 1990

* Nelson 1981

* Palm 1981

* Real Estate Counseling Group of Connecticut 1987

* Roback 1982

* Schmalensee et al. 1.975

* Skaburskis 1989

* Smith and Desvousges 1986b

* Yezer and Rubin 1987

\section{MIGRA'TION}

Clark and Cosgrove 1991

Cushing 198'7

Evans 1990

Frox et al. 1989

Graves 1979

Graves 1980

Graves and Linneman 1.979

Graves ot al., 1984

Greenwood and Hunt 1989

Greenwood et al, 1991

Planning Information Corporation 1.988

Schachter and Althaus 1982

Schachter and Althaus 1989

Sjaastad 1962

\section{NUCLEAR POWER, WASTES}

Boyle 1989

De Boer and Catsburg 1988

Easterling and Kunreuther 1990

Fischoff et al. 1983

Flynn et al. 1990

* Freudenburg and Baxter 1984

* Gamble and Downing 1981

* Gamble et al. 1978 
* Gardner et al. 1982

* Goldhaber et al. 1983

* Hohenemser et al. 1977

"Hughey et al. 1983

" Johnson and Zeigler 1986

* Kasperson et al. 1980 Kunrouther et al. 1988a Kunreuther et al. 1988b Kunreuther et al. 1990 Kunreuther and Slovic 1989

* Lindell and Earle 1983 Maderthaner et al. 1976

* Manning 1982 Mitchell 1980

* Nelkin 1981

* Nelson 1981

* Schneider 1986

* Shakow and Goble 1982 Slovic et al. 1981

Slovic et al. 1989

Slovic et al. 1990a

* Smith and Desvousges 1986b

* Willard and Swenson 1984

\section{PROPERTY VALUES}

* Baker 1986 Bernknopf et al. 1990 Blomquist 1974

* Brookshire et al. 1985

* Freeman 1979

* Gamble and Downing 1.981

* Gamble et al. 1978

* Goldhaber et al. 1983 Hoehn et al. 1987 Kohlhase 1991

* MacDonald et al. 1987 MicClelland et al. 1990

Michaels and Smith 1990

* Nelson 1981

* Park and Miller 1982

* Payne et al. 1987

* Real Estate Counseling Group of Connecticut 1987

* Roback 1982

* Schmalensee et al. 1975

* Skaburskis 1989

* Smith and Desvousges 1986b

* Yezer and Rubin 1987 


\section{RISK (PERCEPTIONS, ATTITUDES)}

* Baker et al. 1977

* Baker 1986

* Behr and Iyengar 1983

Bernknopf et al. 1990

* Brookshire et al. 1985

Burns et al. 1990

De Boer and Catsburg 1988

* Desvousges and Smith 1983

Easterling and Kunreuther 1990

* Elliott 1984

* Fields and Schuman 1976

* Fischoff 1985

Fischoff et al. 1983

Flynn et al. 1990

* Gardner et al. 1982

* Giannici and Gallızzo 1983

* Goldhaber et al. 1983 Hadden 1991

* Hallman and Wandersman 1989

* Harding and Eiser 1984

* Hawkes et al. 1984 Herzog and Schlottmann 1990

* Johnson and Tversky 1984

* Johnson and Zeigler 1986 Kaspersun et al. 1988 Kiecolt and Nigg 1982 Kunreuther et al. 1988a Kunreuther et al. $1988 \mathrm{~b}$ Kunreuther and Slovic 1989 Kunreuther et al. 1900

* Lindell and Earle 1983

* MacDonald et al. 1987 McClelland et al. 1990 Maderthaner et al. 1976

* Manning 1982 Mazur and Hall 1990 Mitchell 1980

* Palm 1981

* Park and Miller 1982

* Shakow and Goble 1982 Slovic et al. 1981 Slovic et al. 1989 Slovic et al. 1990a

* Smith and Desvousges 1986a

* Swartzman et al. 1985 Wildavsky and Dake 1990

* Yezer and Rubin 1987 


\section{RISK (THEORY, DECISION PROCESS)}

* Aschenbrenner 1978

* Bar-Hillel 1980

* Cohen et al. 1985

* Covello 1987

* Dardis 1983

* Daruis et al. 1983

* Edwards and von Winterfeldt 1987

* Fischoff 1979

* Fischoff et al. 1978

* Fischoff et al. 1984

* Kahnemar and Tversky 1979

* Kahneman and Tversky 1984

* Kasperson 1983

* Lopes 1983 Popper 1983

* Slovic 1987

* Tversky and Kahneman 1981

* Wallsten and Budescu 1983

* Willard and Swenson 1984

\section{TOURISM, TRAVEL, AND RECREATION}

Bernknopf et al. 1990

Easterling and Kunreuther 1990

* Fesenmaier 1985

Kunreuther et al. $1988 \mathrm{~b}$

Kunreuther and Slovic 1989

* Malamud 1973

* Seller et al. 1985

* Uysal and Crompton 1985

\section{UTILITY THEORY}

* Brookshire and Crocker 1981

* Brookshire et al. 1985

* Covello 1987

* Dardis et al. 1983

* Desvousges and Smith 1983

* Edwards and von Winterfeldt 1987

* Gregory and Lichtenstein 1987

* Kahneman and Tversky 1979

* Weinrich 1986 


\section{WAGES}

Henderson 1982

Herzog and Schlottmann 1990

Hoehn et al. 1987

* Roback 1982 


\title{
5 ABSTRACTS
}

\begin{abstract}
Author(s) Bernknopf, R.L., D.S. Brookshire, and M.A. Thayer
Date $\quad 1990$

Title Earthquake and Volcano Hazard Notices: an Economic Evaluation of Changes in Risk Perceptions
\end{abstract}

Reference Journal of Environmental Economics and Management, 18:35-49

\section{KEY WORDS}

Disamenities. Perceived risk. Tourism. Property values.

\begin{abstract}
The authors examine the effects on economic activity and risk perceptions related to public notices of earthquake and volcanic activity hazards. A survey of Mammoth Lakes, California, property owners (1190 respondents) provides information on the risk levels people recall perceiving at points in time related to the hazard notification process. While perceptions of mortality risks returned to prenotice levels after the hazard notice was withdrawn, perceptions of risks to property remained heightened.

A stock adjustment model is used to estimate the effects of hazard notices on recreational visits to the area and investment in property, as measured by the number of annual housing starts. Time series data for 11 western wirter recreation sites were employed. In the visitation equation, coefficients on income and hazard notices were somewhat unstable in alternative model specifications, leading to the authors' conclusion that visitation was unaffected by the hazard notices. For investment in new housing, hazard notices have a significantly negative effect. Using a hedonic framework, the authors estimate that hazard information had a significant, negative impact on property values.
\end{abstract}


Author(s) Blomquist, G.

Date 1974

Title The Effect of Electric Utility Power Plant Location on Area Property Value

Reference Land Economics, 50:97-100

\section{KEY WORDS}

Amenities. Hedonic methods. Property values.

\section{ABSTRACT}

The impacts of a coal-fired power plant on property values are examined using an intracity hedonic model on data for Winnetka, Illinois, and three adjacent communities. Mean property values from 1970 census block data are used as the dependent variable, with average number of rooms as the only measure controlling for variation in housing characteristics. Distance measures are employed for (dis)amenities such as railroad tracks, parks and commercial districts.

The author seeks to identify the distance from the power plant at which impacts on property values are no longer detectable. This distance is found to be 11,500 feet. Within this distance, residential property values increase $0.9 \%$ for every $10 \%$ increase in distance from the power plant. 
Author(s) Boyle, M.R.

Date 1989

Title Assessment of the Impact of a Nuclear Waste Repository at Yucca Mountain on the Economic Development Potential of Las Vegas, Clark County and the Surrounding Area

Reference State of Nevada, Nuclear Waste Project Office, Las Vegas, NWPO-SE-016-89

\section{KEY WORDS}

Economic development. Nuclear waste.

\section{ABSTRACT}

This report assesses the potential impacts of the proposed Yucca Mountain repository on future economic development and competitiveness of the southern Nevada economy. It finds that the repository would reduce the competitiveness of the area by causing a $20 \%$ decline in people's image of the area's physical environment and atmosphere.

The Growth Strategies Organization model was used to produce forecasts of the southern Nevada economy under two assumptions. The first assumption is that steps are taken to improve both the image and quality of life in southern Nevada, and that these steps are successful. These steps include improvements in the labor force and quality of educational facilities. The second assumption is that a nuclear waste repository becomes operational during the first decade of the 21st century.

It is the difference in these projections that is used to define the potential repository impacts. However, the basis for assuming that the repository induces a $20 \%$ decline is not documented, nor are the other industry-specific impacts. The findings appear to be completely dependent on these assumptions. 
Author(s) Burns, W., P. Slovic, R. Kasperson, J. Kasperson, O. Renn, and S. Emani

Date $\quad 1990$

Title Social Amplification of Risk: An Empirical Study

Reference State of Nevada, Nuclear Waste Project Office, Las Vegas, NWPO-SE-027-90, September

\title{
KEY WORDS
}

Risk. Risk amplification.

\begin{abstract}
This study attempts to empirically test Kasperson's theory of social amplification of risk. This entailed gathering data through individual (student and expert) and Delphi group methods. One hundred and twenty-eight hazard-related events selected from the New York Times Index for the 1976-1987 time period were coded along a variety of dimensions or variables. Covariance structure analysis (EQS) and partial least squares (PLS) analysis were used to test the theoretical framework concerning the level or degree of social impacts of hazard-related events. The authors report that the theory is supported by the analysis. The scale (number of individuals and size of area affected) of the event influenced the dependent variable of societal impacts (consisting of political and economic impacts), primarily through the intervening variables of media coverage and public response. Perceptions of managerial incompetence, the number of casualties, and the event's "signal effects" also had varying effects on public assessments of future hazards, media coverage, and public response. The report concludes that additional research is needed to fully clarify relationships between the factors affecting the social amplification of risks.
\end{abstract}


Author(s) Clark, D.E., and J.C. Cosgrove

Date 1991

Title Amenities versus Labor Market Opportunities: Choosing the Optimal Distance to Move

Reference Journal of Regional Science, 31(3):311-328

\title{
KEY WORDS
}

Migration. Amenities.

\begin{abstract}
The individual decision to move between locations involves a comparison of the benefits and costs associated with various alternative locations. This choice implies that when choosing an optimal distance to move, the marginal benefits of a given distance will be equated with marginal costs. One implication of a model of optimal distance is that factors which increase marginal cost should reduce the optimal distance moved, while factors which increase marginal benefit should have the reverse effect, increasing the optimal distance.

This model is applied to test the importance in migration decisions of labor market opportunities vis-a-vis amenity improvements. The model is applied to a sample of individuals who moved between metropolitan areas over the 1975-1980 period. The individual migration data is taken from the 1980 Public Use Microdata Sample. The findings offer support for both the disequilibrium and equilibrium models of migration. After controlling for a wide range of personal characteristics, both improved labor market opportunities and improved amenities increase the distance moved.
\end{abstract}


$\begin{array}{ll}\text { Author(s) } & \text { Cushing, B.J. } \\ \text { Date } & 1987 \\ \text { Title } & \text { Location-Specific Amenities, Topography, and Population Migration }\end{array}$

Reference The Annals of Regional Science, 21(2):74-85

\title{
KEY WORDS
}

Migration. Amenities.

\begin{abstract}
Numerous recent studies consider the influence of one or more climatic amenities on migration decisions. However, while major coastlines and mountains represent relatively dramatic topographical features and would be expected to have some influence on the decision to migrate, at least the latter has been largely ignored in the literature. The author attempts to fill that void by incorporating an index of terrain in a model of statewide migration flows. The empirical model specifies the migration variable as migration into state $j$ (1980) from state $l$ (since 1975) divided by those migrating out of state $i$ (since 1975). Thus, the model explains the allocation of those who migrated and ignores those who did not migrate, and as a result, only destination measures (for state $j$ ) need to be considered in the list of determinants.
\end{abstract}

Among the important determinants are several measures of climate (i.e., temperature extremes, available sunshine, wind speed, and humidity), the proximity of the states (i.e., the distance between principal cities of the two states, and adjacency), economic opportunity (i.e., employment growth and income levels) and characteristics of the resident populations (i.e., levels of population, percent of the population in state $j$ born in state $i$, and percent of population in state $j$ that is in the military). Also included is a continuous measure of topography (where a value of 1 denotes the flattest local relief and an index value of 9 represents the most mountainous) and a measure of coastal access ( 2 denotes primary coastal, 1 denotes somewhat coastal, and 0 denotes no coastal access).

The author considers two hypotheses. The first is that amenities (including topography) are important determinants of migration behavior. Among the climatic amenities, temperature extremes display the strongest influence on migration. Proximity also displays an important influence, with greater distance deterring migration, and adjacency of the two states enhancing migration. Economic opportunity measures are statistically important, with employment growth strongly enhancing migration and income levels serving as a deterrent. Finally, the measures of coastal access and terrain display the anticipated positive influence 
on migration. The sacond hypothesis is that amenities can be equilibrating; that is, migrants should be observed moving from low-amenity to high-amenity regions. The latter hypothesis is not confirmed empirically. 
Author(s) De Boer, C., and I. Catsburgr

Date 1.988

Title The Polls - a Report: The Impaot of Nuclear Accidents on Attitudes Touard Nuclear Energy

Reference Public Opinion Quarterly, 62 (summer):254-261

\title{
KEY WORDS
}

Accidents. Nuclear power. Attitudes.

\begin{abstract}
ABS'TRAC'T
The polls found that public perception of nuclear power plants in the United States did not vary after the Three Mile Island accident. In Great Britain, public opinion changed about nuclear power plants after the Chemobyl accident, yet one year later the results were similar to those before the accident. When asked questions about safety, the British supported building nuclear power plants before Chernobyl, then support decreased during the Chernobyl incident, and support returned to normal a year later. In the same time period, the number of people opposed to nuclear power plants being built five miles from their house increased in the United States. The major conclusion of this article is that any changes of opinion that occurred were only temporary.
\end{abstract}




\begin{abstract}
Author(s) Eastorling D, and H. Kunreuther
Date $\quad 1990$

Title The Vulnerability of the Convention Industry to the Siting of a High Level Nuclear Waste Repository
\end{abstract}

Reference State of Nevada, Nuclear Waste Project Office, Las Vegas, NWPO-Star-031.90, September

\title{
KEY WORDS
}

Tourism. Nuclear waste. Percelved risk.

\begin{abstract}
ABSTRAC'T
During 1988, conventions and trade shows drew 1.7 million people to Las Vegas and added over $\$ 1$ billion in gross revenues to the economy. Although the authors indicate that a study by Titus for the Nevada Nuclear Waste Project Office did not find negative impacts on convention activity from Nevada Test Site nuclear activity, they investigated the possibility of effects from the proposed high-level waste repository. The author's surveyed both convention attenders and planners to assess the sensitivity of their decision making to perceived risks of a repository.

With convention attenders, a survey was used that explored the role of environmental conditions, city image, and noxious facility proximity on attendance decisions. Respondents included 600 members of six national associations that had recently met in Las Vegas. The likelihood of attendance at the next meeting was significantly related to environmental conditions for members of three of the organizations. Scores based on the resporilants' images of each city were significantly related to meeting attendance for the entire sample. When asked if they would change a tentative decision to attend a convention if they learned that a repository lay within 100 miles of the city, $23 \%$ indicated that they probably or definitely would not attend.
\end{abstract}

A sample of 153 meeting planners was surveyed regarding the possible effect of various repository activity scenarios on meeting location decisions. The scenarios varied both riskrelated events and patterns of media coverage of repository activity. Even in the case of an accident-free, ten-year history of repository operation, $30 \%$ of planners indicated that they would lower the rank of the host city in choosing a location. With a scenario of recurrent events and media amplification, 48\% indicated they would exclude Las Vegas from consideration. 
Author(s) Evans, A.W.

Date $\quad 1990$

Title The Assumption of Equilibrium in the Analysts of Migration and Interregional Differences: A Review of Some Recent Resectroh

Reference Journal of Regional Science, 30(4):515.532

\title{
KEY WORDS
}

Migration. Amenities.

\begin{abstract}
In order to use interregional wage and property value diffententials as a reflection of amenity valuation, the assumption of equilibrium is imposed. If this assumption is valid, then implicit price estimates also reflect willingness to pay. However, if a region is in disequilibrium, then the equality between the implicit price estimate and the marginal willingness-to-pay is not found. Rather, amenities will be overvalued in regions where out-migration is occurring, while they are undervalued when in-migration is occurring. This paper reviews the relovant research to determine whother the assumption of equilibrium is valid.
\end{abstract}

In considering the available evidence, the author argues that while gross migration fiows in and out of a region are highly correlated, they are not in fact equal (a requirement for equilibrium). Thus, positive or negative net migration is taking place. Second, the author cites evidence that migrants are drawn to moderate climates and away from temperature extremes. This is inconsistent with the notion of equilibrium, since wage and property values would compensate for such disamenities in the presence of equilibrium, and no net migration would occur.

When a region is in disequilibrium, regional adjustment in employment and population to different equilibrium values is found empirically to be small. This suggests that although there is adjustment toward equilibrium when a disturbance occurs, that adjustment is far from instantaneous. The paper concludes by arguing that there is little support for the contention that regions are in equilibrium and that, as a result, interregional differences in wages and property values need not represent utility differences. 
Author(s) Fischoff, B., P. Slovic, and S, Lichtenstoin

Date 1983

Title The Public us, the Experts: Percedved us. Actual Disagreements about Risks of Nuclear Power

Reference in The Analysis of Actual Versus Perceived Risks, Vincent T. Covello et al., eds., Plenum Press, New York, pp. 235-249

\title{
KEY WORDS
}

Perceived risk. Nuclear power. Attitudes.

\begin{abstract}
Six reasons are given why "disagreements between the public and the experts need not be interpreted as clashes between actual and perceived rim."

The first reason is that misconceptions exist about differences between "actual" and "perceived" risks. Actual risks exist, but no one can measure them exactly. Perception is involved in everything a person knows about the risks. The experts try to be objective, but even what people generally call "actual risk" is partially determined by scientific judgment. Being objective means an expert could reach the same conclusion using the same procedure as another expert and not be influenced by their views or interests (values).

The second reason is that there are differences in the use of language between lay people and experts. Semantics play an important part in misunderstandings. Words such as "risk," "voluntary," and "exposure" may have different meanings and implications for experts and population subgroups.
\end{abstract}

The third reason is that lay people and experts are addressing different problems. Risks are never accepted for their own sake but are considered in terms of benefits and costs of alternative options. The option with the highest risk may have more benefits and therefore may be chosen over a lower-risk option. Even if the facts can be agreed upon and people share similar values, the acceptability of risks still may not be agreed upon because people deal with problems "with different sets of alternatives or a different set of relevant consequences."

The fourth reason is that arguments about substance are confused with arguments about form and vico versa. When people not involved with the "risk community" try to argue, they either "may try to master the technical detail, or they may concentrate on monitoring and shaping the risk management process itself." Since the latter is easier for nonexperts, they tend to argue about the method of study rather than the findings. Criticism of scientific 
assessments may be used as a delaying tactic or as a strategic method of shifting the ground of debate

The fifth reason is that disagreements about what is feasible occur between lay people and experts. Experts criticize lay people for putting all their efforts toward "miedirected" risk issues. One reason for this misdirection of effort is that people need to feel they can make a difference. If a large risk exists and people feel that they cannot take "effective action," then they will focus on smaller risk issues.

The sixth reason is that the facts are looked at differently by experts and lay people. Lay people may receive all their information from the experts yet see the facts differently. This difference occurs because the message did not "get through intact." 
Author(s) Flynn, J.H., P. Slovic, C.K. Mertz, and J. Toma

Date 1990

Title Evaluations of Yucca Mountain Survey Findings about the Attitudes, Opinions, and Evaluations of Nuclear Waste Disposal and Yucca Mountain, Nevada

Reference State of Nevada, Nuclear Waste Project Office, Las Vegas, NWPO-SE-029-90, September

\section{KEY WORIS}

Nuclear waste. Attitudes.

\section{ABSTRACT}

Responses to surveys of Nevada residents, Southern California residents, and the U.S. population conducted during the fall of 1989 are summarized here. Similarly strong concern about the environmental effects of technology was found in all three surveys. Comparisons of nuclear waste-related activities to nther technologies indicated that the nuclear activity is "most feared and least acceptable."

Though females rated risks of the repository program higher than males did in all three surveys, no other demographic characteristics were clearly linked to risk perception. However, there is a high degree of association between opposition to nuclear power plant construction and opposition to the repository. A majority of all respondents opposes construction of new nuclear plants. In evaluating various aspects of the physical risks of repository operations, there was evidence in all three surveys that the majority considers the risks to be moderate to high.

Nevada residents showed strong support for the State's opposition to the repository siting at Yacca Mountain. Almost three-fourths favored opposition even if it means losing potential repository benefits. Their support for the State's policy is based on concern about health effects, equity issues, fear of economic impacts, and distrust of DOE management capability. The percentage of Nevadans feeling that repository siting could not be successfully opposed has declined by $35 \%$ since 1.987 , to $53 \%$. 
Author(s) Fox, W.F., H.W. Herzog, and A.M. Schlottmann

Date $\quad 1989$

Title Metropolitan Fiscal Structure and Migration

Reference Journal of Regional Science, 29(4):523-536

\title{
KEY WORDS
}

Migration. Amenities.

\begin{abstract}
Since the early work of Charles Tiebout, residents have been shown to "vote with their feet," moving between various local jurisdictions to that location which best serves their preferences. This paper extends the Tiebout model to an analysis of the decision to move, the decision to depart a metropolitan area, and the decision to enter a metropolitan area. These individual decisions should be influenced by personal characteristics, characteristics of the metropolitan area, and determinants of the urban fiscal structure.

The paper uses data from the 1980 Public Use Microdata Sample. All three decisions are found to be sensitive in varying degrees to the fiscal characteristics of the metropolitan area. The strongest role is played by expenditures in the decision to depart a metropolitan area. Specifically, spending on education and parks and recreation tend to reduce the likelihood of migration out of a metropolitan area, while expenditures on welfare and police and fire have the opposite effect, increasing the likelihood of movement out of a metropolitan area.
\end{abstract}


$\begin{array}{ll}\text { Author(s) } & \text { Graves, P.E. } \\ \text { Date } & 1979 \\ \text { Title } & \text { A Life-Cycle Empirical Analysis of Migration and Climate, by Race }\end{array}$

Reference Journal of Urban Economics, 6:135-147

\title{
KEY WORDS
}

Migration. Amenities.

\begin{abstract}
Migration within an equilibrium context implies that even if regional labor markets are in equilibrium, households may still be motivated to move. This migration may be motivated by two factors. First, a change in life stage may change an individual's demand for nontraded amenities which are site-specific. Second, a change in income may have a similar impact on such demand. Both events require a move in order for demand to be satisfied. This paper hypothesizes that migration is age-specific and may be race-specific as well, due to the differences in income levels between the races.

The author uses net migration rates for 137 SMSAs over the period 1960-1970. Economic opportunities are measured by income levels and by unemployment rates in the metropolitan area. Climatic amenities are measured by hot and cold temperature extremes, temperature variation, wind speed, and humidity. The findings show that amenities increase in importance as individuals age. Young migrants of both races are more interested in moving to areas with lower unemployment rates and higher income levels than are older migrants, who value less temperature variation and less humidity. In addition, climate appear to be relatively more important to whites as compared to blacks.
\end{abstract}


Author(s) Graves, P.E.

Date $\quad 1980$

Title Migration and Climate

Reference. Journal of Regional Science, 20(2):227-237

\title{
KEY WORDS
}

Migration. Amenities.

\begin{abstract}
The disequilibrium approach to migration stems from the early work of Sjaastad, in which workers migrate in response to gains in real earnings over space. Locations with relatively high real income should experience lower out-migration and higher in-migration. The equilibrium approach argues alternatively that growth in income may result in enhanced demand for location-specific amenities. For example, an increased demand for recreational amenities may result in greater demand for good climate, which is necessary for enjoyment of outdoor recreational amenicies. If income differentials between regions are compensating for the amenity mix, then no relationship between income levels and in- or out-migration necessarily exists.
\end{abstract}

The author uses gross in- and out-migration rates for 49 SMSAs for whites, by age groups. The data cover the years 1965-1970. Only 42 SMSAs have complete data for nonwhites. Independent variables include average income and unemployment rates for each of the age groups considered. Also included are five measures of climate: annual temperature variance, annual average wind speed, annual average humidity, average annual cooling degree days, and average annual heating degree days.

The findings for white males show that climate is an important determinant of in- and out-migration. Some amenities are normal (i.e., demand rising with enhanced income) and others are inferior (i.e., demand falling with income growth). In addition, there appears to be a life-cycle effect, with older migrants responding differently from younger migrants, although no consistent pattern emerges. When considering income, out-migration appears to be significantly enhanced by high income levels, while in-migration is not effected significantly. This is inconsistent with the disequilibrium model. High unemployment rates do not significantly influence (and actually reduce) out-migration for those of ages 25-34. In considering nonwhites, it is found that they are more responsive to differential economic opportunity than whites. Climate appears to have a similar influence on nonwhites as it does whites. Sex differences are found to be relatively minor, with climate affecting both groups almost identically. 
An examination of manufacturing wage growth provides additional evidence in support of the role of amenities. High-amenity locations should experience lower than average wage growth, since amenities should enhance in-migration and lower out-migration. Low-amenity locations should experience higher than average wage growth. An examination of the 49 SMSAs examined above shows that high humidity levels and high wind speed (low-amenity locations) significantly increase manufacturing wage growth. 
Author(s) Graves, P.E., and P.D. Linneman

Date 1979

Title Household Migration: Theoretical and Empirical Results

Reference Journal of Urban Economics, 6:383-404

\title{
KEY WORDS
}

Migration. Amenities.

\begin{abstract}
Since the early 1960s, migration has been viewed in the context of individual search for utility maximization. Migration occurs so long as the marginal benefits of a move exceed the marginal ccsts. However, the focus of early research was relatively narrow, emphasizing improvements in labor earnings as the primary benefit. This paper generalizes the utilitymaximizing framework to consider the importance of goods that are not traded (i.e., sitespecific). Nontraded goods include such factors as local climate and environmental goods. It is the hypothesis of this paper that there is a demand for nontraded goods, and if that level of demand changes, then the new level of demand can be satisfied by migration.
\end{abstract}

The paper develops a theoretical model in which the probability of migration depends on several factors: these include (1) the divergence between desired site-specific goods and the actual levels consumed at the present site and (2) the full cost of moving. The former may change as a result of changes in demand for these goods (e.g., important events in a family such as birth or graduation of a child, divorce, etc.), or changes in local supply (e.g., improvements in school systems).

The data come from the Panel Study of Income Dynamics. The probability of migration from one year to another is hypothesized to be a function of market discrimination factors (which limit choices and reduce expected benefits from a move), nontraded good demand shifters, and factors which affect migration costs. The model is estimated for two time periods, 1970-1971 and 1971-1972. In general, the findings support theoretical expectations. Variables which limit opportunities reduce the likelihood of migration (e.g., sex of household head); variables which alter the demand for nontraded goods (e.g., changes in family composition) increase the likelihood of migration; and factors which increase the cost of migration (e.g., the presence of children in school) reduce migration probability. 


\begin{abstract}
Author(s) Graves, P.E., R.L. Sexton, and T.A. Knapp
Date 1984

Title A Multi-Disciplinary Interpretation of Migration: Amenity Capitalization in Both Land and Labor Markets
\end{abstract}

Reference Annals of Regional Science, 18(2):35-44

\title{
KEY WORDS
}

Migration. Amenities.

\begin{abstract}
The authors argue that if migrants weigh the expected benefits against expected costs in their location choice, then one must consider the role that information plays in those choices. Specifically, one can consider the differences that exist between a migrant who possesses perfect information as compared with one whose information is imperfect. In the perfect information world, characteristics of all possible locations are known by potential migrants. Hence, utility levels are everywhere equal, since migrants will move in response to utility differentials which generate utility-equalizing land rent differentials (i.e., higher rents in regions with better amenities). Determinants of migration in this framework include life-cycle changes (e.g., graduation from college) which cause a change in demand for amenities. Alternatively, changes in the supply of an amenity in a location (such as an increase in the crime rate in a neighborhood) can also lead to migration.
\end{abstract}

By comparison, imperfect information implies that perceptions about different locations evolve over time, and, as a result, adjustments to new equilibria may take considerable time. These changing perceptions may take the form of discoveries about characteristics of a particular location which alter the perceived benefits or costs (e.g., the discovery of gold in California) or slow information transfer (e.g., information about superior amenities may take time to be fully perceived by migrants). To the extent that information is not available about the amenity differences in different regions, utility levels may differ because local land rents are not compensating.

An empirical test of the existence of complete information about amenities in a particular region rests on whether amenity differentials affect migration. The authors propose to use local rents as an approximation for amenities and point to several advantages of such an approach. The primary advantages are econ ometric. Since all perceived amenity differentials that matter to migrants will be reflected in rent differentials, one need not be concerned about whether all important amenities have been included in the model if land rent is included. In addition, problems with colinearity between various amenities (e.g., crime rates 
and museum availability may be highly correlated) are avoided when one measure of amenities is used.

The empirical model considers net migration for 137 metropolitan areas over the period 1960-1970. Explanatory variables include metropolitan-areawide unemployment rates, median income levels, and median rent. The findings show that the unemployment rate is unimportant, whereas migrants motivated by incume move toward high-income regions. Finally, migrants appear to move toward high-rent areas. This implies that the assumption of full information is supported empirically since higher rents must imply higher amenity levels. 
Author(s) Greenwood, M.J., and G.L. Hunt

Date 1989

Title Jobs versus Amenities in the Analysis of Metropolitan Migration

Reference Journal of Urban Economics, 25(1):1-16

\section{KEY WORDS}

Migration. Amenities.

\section{ABSTRACT}

Since the late 1970s, amenities have been recognized as one possible motivation for migration behavior. In addition, demand for amenities should rise with income if such goods are normal goods, and amenity demand should also depend upon an individual's position in the life cycle. The work of Graves supports this contention in two ways. First, when labor market opportunities are controlled, amenities remain important determinants of migration. Second, age, which is one indication of position in the life cycle, also appears to be an important factor as older households are more concerned with amenities than those that are younger. This paper challenges this contention, arguing that the case for the importance of amenities in the migration decision is overstated.

If labor market opportunities are correlated with amenities, then improper control of labor market opportunities will attribute more importance to amenities than is warranted. The authors propose to measure economic opportunities using endogenously determined employment growth in a region, as opposed to the unemployment and income measures used by Graves.

A unique data source employed in this paper is from the Social Security Continuous Work History Sample covering the years 1958-1975, and a separate migration equation is estimated for each year of the sample. Migration is measured by employment migration. Among the determinants of migration are income, employment growth, and amenities measuring climate. With employment growth included in the equations, amenities are typically unimportant statistically, whereas wage rates and employment growth are found to be statistically important. When employment growth is excluded, the amenity variables perform a little more strongly, although support remains weak. The authors conclude that the case for inclusion of amenities as a motivation for migration is weak at best. 
Author(s) Greenwood, M.J., G.L. Hunt, D.S. Rickman, and G.I. Treyz

Date $\quad 1991$

Title Migration, Regional Equilibrium, and the Estimation of Compensating Differentials

Reference American Economic Review, 81(5):1382-1390

\title{
KEY WORDS
}

Migration. Amenities.

\begin{abstract}
The insights of interregional hedonic models rely on the assumption that regional labor and land markets are in equilibrium. If equilibrium can be assumed, then implicit values on regional amenities can be derived from regional wage and land price differentials. By contrast, if a region is not in equilibrium, then either in-migration or out-migration will affect the local wages and property values, thereby distorting implicit value estimates. Alan Evans has questioned whether equilibrium can be defended in light of empirical data which show that the speed of adjustment to a new equilibrium is slow.
\end{abstract}

This paper considers the issue of compensating differentials in a migration framework. 'The empirical model uses data for the period 1971-1988 for 50 states and Washington, D.C., and estimates a relationship between migration rates and relative expected income while controlling for the influence of amenities. Since regional equilibrium implies that area net migration is zero, the authors can equate the estimated migration equation to zero, solve for income, and thus determine the hypothetical level of income that would compensate for the amenity level in the area. That level of income can then be compared with the actual level of income for the region to determine whether that region is in equilibrium. The findings suggest that there is little support for the assumption of equilibrium. Amenity-rich states tend to overcompensate workers and amenity-poor states tend to undercompensate workers, and implicit values are distorted. The authors then examine the extent to which the identified problem leads to faulty conclusions. A quality-of-life index (QOLI) is estimated using actual income compensation and the hypothetical level implied by equilibrium. The QOLI comparison shows that the erroneous assumption of equilibriurn leads to misclassification of regions as high-versus low-quality-of-life areas in very few instances. The authors conclude that while the assumption of equilibrium is not justified, the errors generated by the assumption appear to be relatively minor. 
Author(s) Hadden, S,G.

Date 1991

Titlo Public Perception of Hazardous Waste

Reference Risk Analysis, 11(1):47-57

\title{
KEY WORDS
}

Hazardous waste, Risk perception.

\begin{abstract}
ABS'TRACT
The author focuses on the gap between public and expert assessment of risks. This gap is a problem for two reasons; it results in 1ess-than-optimal expenditures of funds to reduce risks, and it precludes the construction of socially advantageous facilities. The author suggests that differences in the ways the public and experts assess risks and the level of public participation in risk policy decisions are the causes of this gap. She cites past surveys and earlier work to show both a decline in public deference to expert and government opinion and policies and a corresponding increase in public action and desire for participation in policy making. The article concludes with a discussion of the important role of feelings of personal control as an element in risk perceptions and suggests ways to enhance public: participation.
\end{abstract}


Author(s) Henderson, J.V.

Date 1982

Title Evaluating Consumer Amenittes and Interregional Welfare Differences

Reference Journal of Urban Economics, 11(1): 32-59

\section{KEY WORDS}

Wages, Amenities, Regional welfare differences.

\section{ABSTRACT}

In theoretical models of systems of cities, one of the important determinants of city size is the mix of amenities at the city location. The value of a city's amenity endowment can be inferred from the wage premium that exists for that city. Cities with good amenities should offer lower real wages than amenity-poor cities. Thus, welfare differences can exist if after accounting for cost-of-living and amenity differentials, various regions offer different wages. Numerous other authors suggest that these nominal wage differentials represent equal real wages, that is, the differences merely represent differences in the cost of living. The author shows in this paper that when amenities and cost of living are considered, wages are not found to be equal. Rather, real wages and hence welfare is found to be higher in the south and lower in the north. This is consistent with the observed direction of migration flows.

The author first establishes the conditions under which wage differences can be used to value amenities in a particular location. If average amenity levels for a city are considered (e.g,, the average level of air quality), then the average cost of living for that city must also be controlled for the wage premium to reflect the value of the amenity. The empirical model makes use of the May 1978 Consumer Population Survey. The survey contains information on individual male wage earners for 24 SMSAs and consolidated metropolitan areas. Amenities considered include murder and burglary rates, percentage of available sunshine, mean July temperature, miles of beach per 100,000 population, city-wide unemployment rate, and percentage of population over 25 years with a high school diploma. In addition, city population is included as a proxy for other city-size-related amenities, and variables representing broadly defined census regions are included to capture regional welfare differences. Average cost-of-living differences are controlled using the Bureau of Labor Statistics Family Budget Indices. Findings are robust regardless of whether wages are expressed in before- or after-tax terms and regardless of the way in which cost of living is controlled. Controlling for cost-of-living differences between cities, wages increase as amenities fall and rise as amenities are reduced. Moreover, regional differences in welfare, as reflected in real wage differences after controlling for amenities, are found to be consistent 
with observed migration flows, Real wages are relatively higher in. the South and West and lower in the North and Midwest. This real wage differential is strongest for worker's who are young and educated. 


\begin{abstract}
Author(s) Herzog, H., and A. Schlottmanu
Date 1990

Title Valuing Risk in the Workplace: Market Price, Willingness to Pay, and the Optimal Proviston of Safety
\end{abstract}

Reference Review of Economics and Statistics, 72(3):463-470

\title{
KEY WORDS
}

Hedonic methods, Perceived risk. Wages.

\begin{abstract}
The authors examine the degree to which market valuations of workplace safety correspond with workers' willingness to pay for risk reduction. Both wages and propensity to change employment are estimated as functions of human capital and labor market control variables and risks (measured by fatal injury rates). A sample was drawn from the 1970 Census microdata of 4,511 white males employed in manufacturing in 1965, and these data were used to estimate the industry-switching equation. The wage equation was estimated on a subgroup totaling 2,954 , limited to those who had not changed employment between 1965 and 1.969 .

Based on the wage equation, risk-compensating differentials comprise $1.9-2.5 \%$ of wages. Based on the industry switching equation, the differential required for risk acceptance is 2.8.5.7\% of wages. From these differences in estimates of risk value, the authors conclude that the market estimates understate workers' willingness to pay for risk reduction. The possible effects on the findings of eliminating marginal workers from the wage equation is not discussed.
\end{abstract}


Author(s) Hoehn J.P., M.C. Berger, and G.C. Blomquist

Date $\quad 1987$

Title A Hedonic Model of Interregional Wages, Rents, and Amenity Values

Reference Journal of Regional Science, 27(4):605-620

\title{
KEY WORDS
}

Hedonic methods. Wages. Property values. Amenities. Hazardous waste.

\begin{abstract}
This study examines the interaction of wages and rents in the valuation of interregional differences in amenities. Hedonic mudels of wages and property values are developed within an interregional equilibrium framework to estimate the net differential attributable to amenity differences amous locations. The 1980 Census Public Use Microdata Sample (PUMS) data are used, with a sample size of 34,414 housing units and 46,004 workers in 285 SMSAs. A flexible functional form was employed in the estimation.

Among the 16 measures of (dis)amenities included are water pollution dischargers, Superfund sites, landfill waste, and hazardous waste disposal sites. While only the number of water pollution dischargers showed the intuitively expected negative effect on property values and positive effect on wages, all show a net negative impact. Thus, the disamenity effects of these activities are capitalized into regional markets.
\end{abstract}


Author(s) Kasperson, R.E., O. Renn, P. Slovic, H.S. Brown, J. Emel, R. Goble, J.X. Kasperson, and S. Ratick

Date 1988

Title The Social Amplification of Risk: Conceptual Framework

Reference Risk Analysis, 8(2):177-187

\title{
KEY WORDS
}

Risk perception.

\begin{abstract}
The authors present a theoretical framework for explaining the gap between the levels of certain risks, as measured by technical experts, and the much greater public concern and reaction to those risks, with resultant social and economic impacts. They suggest that psychological, social, institutional, and cultural processes are involved in such social amplification of risks. The framework focuses on both the communication of the risk event by various parties and the resulting risk-related behavior, which produces a variety of spreading secondary social, political, and economic impacts. Media and social communication channels, individuals' heuristics and values, signal value characteristics of the event, and stigmatization are also considered important parts of the social amplification process. The authors conclude with a discussion of the value of this conceptual framework and steps to its empirical testing and theoretical development.
\end{abstract}




\author{
Author(s) Kiecolt, K.J., and J.M. Nigg \\ Date 1982 \\ Title $\quad$ Mobility and Perceptions of a Hazardous Environment
}

Reference Environment and Behavior, 14(2):131-154

\title{
KEY WORDS
}

Risk perception. Disamenities.

\begin{abstract}
This study explores relationships between plans to move from the Los Angeles area and perceptions of earthquake threat. A recursive block variable model is estimated using 1977 survey data for a representative sample $(n=1450)$. The dependent variable, the intensity of plans to move, is regressed on a group of objective risk measures, individ il $_{\text {and }}$ anousehold characteristics, community attachment measures, and variables related to earthquake risk perception. The latter includes measures of threat awareness, past experience of quakes, and coping measures such as insurance purchase.

Household- and community.related variables had the strongest relationships to moving intentions. Objective risk measures did not increase plans to move and the threat awareness measures increased it only slightly. Those who were most fearful of earthquakes were less likely to consider moving, but in general, those with more information about risks and a greater sense of personal risk were more likely to be considering a move.
\end{abstract}


Author(s) Kohlhase, J.

Date $\quad 1991$

Title $\quad$ The Impact of Toxic Waste Sites on Housing Values

Reference Journal of Urban Economics, 30:1-26

\title{
KEY WORDS
}

Hedonic methods. Property values. Hazardous waste. Disamenities.

\begin{abstract}
Property value effects of placing existing hazardous waste sites on the National Priorities (Superfund) List are examined in this study. Housing sales from 1976-1985 in Harris County (Houston area), Texas are analyzed in a hedonic framework. This time period was selected for analysis because it brackets the 1980 start of the ongoing effort to identify and characterize the most hazardous sites. Ten sites in Harris County had been listed as of June 1986.
\end{abstract}

The author estimates a log-linear hedonic model, including distance and distance squared to the nearest waste site; a vector of housing characteristics; a vector of neighborhood characteristics, including average family income; and a time dummy. In comparison to the 1975 and 1980 data, the 1985 estimates indicate the development of a significant price premium for distance from a hazardous waste site. Housing prices increase, at a decreasing rate, up to 6.2 miles from the $S$ : perfund sites. The rubustness of the results is demonstrated by several different model formulations and different treatments of the distance variable.

Property market impacts did not vary with EPA ratings of the severity of the risks at each site. Analysis of one site that had been partially cleaned up, however, showed an absence of distance-related price effects. The author tentatively concludes that site remediation eliminates the property value impacts. 
Author(s) Kunreuther, H., W.H. Desvousges, and P. Slovic

Date 1988a

Title Nevada's Predicament: Public Perceptions of Risk from the Proposed Nuclear Waste Repository

Reference Environment, 30(8):16-33

\title{
KEY WORDS
}

Perceived risk. Nuclear waste.

\begin{abstract}
In 1987, the Nuclear Waste Policy Act was amended to authorize DOE to determine whether Yucca Mountain, Nevada, is a "geologically sound and technically feasible" site for a repository. Nevada is officially opposed to the repository and is doing all it can to disqualify Yucca Mountain on the grounds of unacceptable risks. There is also fear that economic activities will be affected if Nevada is stigmatized as a "nuclear wasteland." As part of a larger program to address these concerns, the authors investigate relevant public attitudes in Nevada and nationwide.
\end{abstract}

Telephone interviews were conducted with 1201 respondents in the U.S. sample and 1001 respondents in the Nevada sample. The response rate was low, limiting generalization of the results to the Nevada population or nationwide. The authors still feel the information provides "insight into the nature of perceptions and attitudes toward the repository." The survey consisted of five different elements, which are (1) view of the repository, in terms of feasibility and desirability; (2) risk perceptions, in terms of characteristics of risk, sources of risk, and the likelihood of accidents; (3) voting behavior, in terms of attitude toward repository, influence of perceived risk, and importance of legal control; (4) willingness to accept compensation, in terms of impact on voting behavior and importance of perceived risk; (5) risk-induced behaviors, in terms of attendance at conventions, retirement decisions, and industrial and professional relocation decisions.

The view of the repository among Nevada respondents was slightly more positive than for the U.S. as a whole, but only a minority saw Nevada as the best or safest location. Nevadans viewed repository risks as more serious than those for the nuclear test site. About a fifth of respondents to both surveys rated repository risks a "10" on a 10-point scale, however the percentage of Nevadans rating risks a "1" was twice that for the U.S. survey. Women rated the risks more highly in both surveys while other demographic characteristics were unrelated to risk perception. The survey findings are consistent on siting the repository, with Yucca Mountain being the most favored of the three candidate sites and nearly half the respondents opposing any of the sites. 
A connection was found between perceived risk and the willingness to accept compensation for repository siting. Among those perceiving low risks, more than half in each survey would accept compensation. In the medium risk perception group, slightly less than $30 \%$ would accept compensation. If the perceived risk was high, few respondents $(10-15 \%)$ would accept compensation. Over 50\% in both surveys agreed that a repository located within 100 miles of an area would make that place less desirable. Slightly more than $40 \%$ of the people claimed that they would be less likely to attend a convention that was located within a 100 miles of the repository. The national survey showed more people not wanting retire within 100 miles of the repository (66\%) than did the Nevada survey (57\%). Over $40 \%$ of both samples indicated that they would alter retirement plans to avoid moving near a repository, even if the change cost them $\$ 5000$.

The results show that people are opposed to having the repository in Nevada and, until the repository is safe enough, people's opposition and concern are not going change. Once the risk is perceived as low, then people will be more willing to accept compensation as "an appropriate policy tool for facilitating its siting." It is still unknown as to whether the repository will deter people from visiting or moving to Nevada. 
Author(s) Kunreuther, H., D. Easterling, W. Deswousges, and P. Slovic

Date 1990

Title Public Attitude toward Siting a High-Level Nuclear Waste Repository in Nevada

Reference Risk Analysis, 10(4):469-484

\title{
KEY WORDS
}

Nuclear waste. Perceived risk.

\begin{abstract}
The authors present and contrast two models of individual choice concerning the Nevada nuclear waste repository: a benefit-cost model reflecting the DOE position and a risk perception model corresponding to the State of Nevada position. These models are tested with data from two telephone surveys of 1201 U.S. households and 1001 Nevada residents. Although empirical support is shown for both models, the risk perception model predictors are reported as having more impressive effects on willingness to vote for the repository. The author's conclude that confidence in DOE's ability to manage the facility, with the resultant decrease in perceived risks (especially to future generations), are important prerequisites to increasing acceptance of the repository. Compensation through monetary payments only increases support for the repository by individuals with low-risk perceptions regarding the project. The authors conclude by discussing changes in institutional relationships and siting procedures which could reduce opposition to the repository.
\end{abstract}


Author(s) Kunreuther, H., D. Easterling, and P. Kleindorfer

Date $\quad 1988 \mathrm{~b}$

Title The Convention Planning Process: Potential Impact of a High-Level Nuclear Waste Repository in Nevada

Reference State of Nevada, Nuclear Waste Project Office, Las Vegas, NWPO-SE-021-90, September

\title{
KEY WORDS
}

Nuclear waste. Tourism. Risk perception.

\begin{abstract}
The authors used survey and interview techniques in order to develop an understanding of the convention planning and decision process and the effects of changing risk perceptions on site selection for a convention. A number of assumptions are employed in the evaluation of the survey responses using ANOVA techniques. The authors recognize that these assumptions create a more or less static model of what is essentially a dynamic market. In interpreting their findings, they clearly recognize the limitations of their approach and the tentative character of their results.

The range of potential negative impacts on convention and meeting activity levels depends upon the severity of the scenario analyzed and the extent of the news coverage associated with any accident related to the repository. The best case scenario for repository construction, with little or no negative news, produced a decline in convention activity of between $3 \%$ and $28 \%$. In the worst case scenarios, with major accidents and wide news coverage, convention activity would decline by between $39 \%$ and $68 \%$. These findings are preliminary, due to the static information provided by the research design and the limited number of convention planners surveyed. The authors recognize these limitations and weaknesses and are cautious concerning the extrapolation of these results without further work.
\end{abstract}




\begin{abstract}
Author(s) Kunreuther, H., and P. Slovic
Date $\quad 1989$

Title Forecasting the Adverse Economic Consequences of a Nuclear Waste Repository in Nevada
\end{abstract}

Reference Presented at the AAAS Annual Meeting, San Francisco, Calif.

\title{
KEY WORDS
}

Nuclear waste. Imagery. Tourism. Risk perception.

\begin{abstract}
This study examines the potential for a high-level nuclear waste repository to stimulate adverse economic impacts in Las Vegas and in Nevada as a whole. The authors expect impacts on tourism, retirement decisions, business location decisions, and convention planning to develop from perceptions of risk and from stigmatization.

A series of surveys were conducted to study imagery and preferences and to link imagery with choices. Three studies were conducted to elicit information about preferences between selected cities and states as potential vacation sites, job locations, and retirement locations. A separate survey of business executives was conducted to explore their preferences between cities and states for purposes of either opening a new business or relocating their current business.

Survey respondents were asked for images they associate with each city and state considered and then were asked to rank these images. Finally, they were asked to provide a separate ranking of cities and states as choices for vacation, retirement, or job sites. The authors developed a summation mechanism that aggregates the preferences across cities and states to predict location choices indicated in the surveys. The overwhelmingly negative imagery associated with the nuclear waste repository is projected to cause adverse economic impacts on the economy of southern Nevada.
\end{abstract}


Author(s) McClelland, G.H., W.D. Schulze, and B. Hurd

Date 1990

Title The Effect of Risk Beliefs on Property Values: A Case Study of a Hazardous Waste Site

Reference Risk Analysis, 10(4):485-497

\title{
KEY WORDS
}

Perceived risk. Property values. Hazardous waste.

\begin{abstract}
ABSTRAC' $T$
Property value impacts are estimated for residences near a Los Angeles area landfil', before and after landfill closure. The landfill, which was originally planned for conversion into a golf course and park, is presently on the National Priorities (Superfund) List.

Fxpert assessments of landfill health risks are reviewed and compared to residents' judgments of the risks. While experts indicated that major present or future health problems due to the site are unlikely, residents' perceptions showed a bimodal distribution. At the high end, risks were perceived as equal to those of smoking a pack of cigarettes daily. Half of the respondents believed that health risks had declined after the landfill closed, though no remedial action had been taken. Proximity to the landfill, having higher income, being female, having children at home, having more education, smelling odor, and exposure to information about the site were all significantly related to greater concern with health risks. Perception of odor, which is correlated with distance, explained over half the variation in risk assessment.

Sales price and structural data for 178 homes near the landfill are used in a hedonic analysis of property values for 1983 through 1985. Aggregate measures of perceived health risk before and after site closure were constructed for small neighborhoods and incorporated in the model. The proportion of the neighborhood perceiving health risks as "high" was found to significantly lower property values. The change in risk perception after closure of the site reduced the property value loss by about half.
\end{abstract}


Author(s) Maderthaner, R., P. Pahner, G. Guttmann, and H.J. Otway

Date $\quad 1976$

Title Perception of Technologtcal Risks: The Effect of Confrontation

Reference International Institute for Applied Systems Analysis, Laxenburg, Austria, Research Memorandum RM-76.53, June

\title{
KEY WORDS
}

Risk perception. Nuclear power.

\begin{abstract}
The theory of "cognitive dissonance" leads the authors to hypothesize that people will tend to alter their attitudes to make them more consistent with facts that confront them. A randomly selected group of 148 residents of Vienna were surveyed as to their perception of the risks of a gas works, district heating facility, oil refinery, mental hospital, nuclear reactor, prison, and airport. The respondents were then grouped into those residing near and far from the nuclear reactor, near and far from the district heating facility, and a control group. Those residing near the reactor rated its risks significantly lower than did those living far from it. All of the groups rated the nuclear reactor as the most risky technology except those living near it, who rated the oil refinery and airport as more risky.
\end{abstract}


Author(s) Mazur, A., and G.S. Hall

Date 1990

Title Effects of Soctal Influence and Measured Exposure Lavel on Response to Radon

Reference Sociological Inquiry, 60(3):274-284

\section{KEY WORDS}

Risk avoidance.

\section{ABS'TRACT}

Mazur and Hall examine factors affecting response to hazardurelated information. They believe that psychological explanations of hazard response are deficient in two ways. The first deficiency is the failure to include "social influences of friends, family, fellow workers, respected public officials, and the mass media." The second deficiency is the failure to consider that "risk perceptions may form afterwards, as part of the ex post facto rationale for one's own behavior, being an effect rather than a cause of the response." Mazur and Hall create a model which includes both moasured risk of the hazard and social influence and treats both as determinants of response to hazard and biased perception of risk.

During 1986-1987, a group of homes in Onondaga County, New York, were selected for measurement of radon levels. Homes with measurements above EPA guidelines were retested and all home owners were advised of the results. Later a questionnaire was malled to learn the home owners' responses to the information about radon levels in the 204 homes that were tested. Questions covered the owners' information-seeking and actual or intended remediation efforts.

The results are consistent with the authors' model of response to hazard. There is a strong and significant correlation between the measured radon level and behavioral responses. This correlation exists for information seeking, taking remedial action, the intention to take remedial action, and reporting of specific concerns about radon.

Mazur and Hall believe that people can obtain a clear impression and respond appropriately to a proximate hazard. If the hazard is distant or diffuse then bias will be more prevalent and it is more likely that people will conform to the social influences surrounding them, such as friends, public officials, and the mass media. 
Author(s) Michuels, G., and V.K. Smith

Date $\quad 1990$

Title Market Segmentation and Valuing Amentties with Hedontc Models: The Casc: of Hazardous Waste Sites

Roferenoe Journal of Urban Economics, 28:223-242

\title{
KEY WORDS
}

Amenities, Hazardous waste. Hedonic methods. Property values.

\begin{abstract}
In large heterogeneous housing markets found in metropolitan areas, ther'e are housing submarkets which may not be adequately characterized by a single hedonic price function. Since realtors act as middlemen in housing markets, an effort was made to develop a classification of the 85 suburban Boston communities into consistent groups by several realtors. A consensual grouping (by two realtors) of the towns into four classes is used as a basis for the submarket analysis.
\end{abstract}

A log-linear model is estimated using ordinary least squares (OLS) for 2182 home sales that occurred between 1977 and 1981. Prices are deflated to 1977 dollars and a time-trend variable and neighborhood characteristics are included as controls. Hazardous waste site impacts are measured by distance to the nearest hazardous waste site and an interaction term to capture the effect of the timing of hazard identification on prices.

Results of the full sample estimation are generally significant and consistent with previous studies. Distance from hazardous waste sites increases home values, and more so after the sites are publicly iaentified. When the submarkets are estimated separately, signs and significance levels on some variables differ both from the total sample and among submarkets. This is true for housing and neighborhood characteristics as well as the hazardous waste site measures. Application of the Brown-Durbin-Evans cusum of squares test revealed parameter instability that did not correspond exactly to the submarket divisions derived from the realtors' ranking. However, most coefficients were found to differ significantly in value across submarkets. 
Author(s) Mitchell, R.,

Date $\quad 1980$

Title Public Opinion and Nuclear Power before and after Three Mile Island

Reference Resources, 64(Jan.-Apr, ):5-8

\title{
KEY WORDS
}

Nuclear power. Attitudes. Accidents.

\begin{abstract}
ABSTRAC'T
In 1977, the Harris Poll found that those who supported nuclear power plants outnumbered those who did not by 3 to 1 . In 1978, the numbers declined to 2 to 1 . In 1979 , after the highly publicized Three Mile Island (TMI) accident, the number of people supporting nuclear power declined sornewhat. However, the majority of people still supported nuclear power.
\end{abstract}

Within one week's time almost everyone had heard of the accident at TMI, but the majority did not view the media as handling the situation well. Forty-seven percent of the people felt the government did a good job of handling the situation. As many as one out of every four people felt the press exaggerated the danger. Forty percent of the people felt the media was "opinionated and emotional," while 38\% felt the media were "basically factual and objective." Despite the negative attitudes toward the media, half of the people felt they were "somewhat informed" and $23 \%$ felt they were "well informed."

Nine months after the accident, the gap between the number of people in favor of nuclear power and those who oppose it declined to $12 \%$ ("half of what it was before the accident"). Two reasons were given for this "mild long-term reaction." One reason was that since no one was hurt in the accident, it made some people look more favorably upon nuclear power, while others believed that it was just by luck that more didn't happen. The second reason given for the mild reaction attributable to the Three Mile Island experience was that the trend against nuclear power was already increasing before the accident occurred.

The polls show that the accident did not alter people's view of nuclear power plant safety. Twenty-one percent felt the plants were "very safe," $46 \%$ felt the plants were "somewhat safe," and 30\% felt the plants were "not so safe." Those believing the that the plants were "not so safe" only increased by $2 \%$ from October of 1978 to immediately after TMI. 
$\begin{array}{ll}\text { Author(s) } & \text { Planning Information Corporation } \\ \text { Date } & 1988 \\ \text { Title } & \text { Retirement Migration and Military Retirement } \\ \text { Reference } & \begin{array}{l}\text { State of Nevada, Nuclear Waste Project Office, Las Vegas, NWPO-SE-001-88, } \\ \text { June }\end{array}\end{array}$

\title{
KEY WORDS
}

Migration.

\begin{abstract}
This report identifies the points of origin of major migratory flows to Nevada and specifically to Clark County. Within the group of in-migrants, the characteristics of retirees and nearretirees (age 55 and older), military retirees, and seasonal migrants are examined in detail. These groups are emphasized because of their external (to Nevada) sources of income. Migration trends are described in detail and projections provided through 2025 and even 2050 for military retirement.
\end{abstract}

Between 1975 and 1980, in-migrants to Clark County outnumbered persons remaining incounty and they outnumbered out-migrants by more than two to one. The ratio of inmigrants to out-migrants increases with the age of the cohort studied. California was the major source of in-migrants $(22.8 \%)$, with the next largest group coming from foreign countries. Retirees make up a disproportionately large share of the California migration flow. Nonlocal income accounts for $10.7 \%$ of total income in Clark County, and $66.9 \%$ of it is received by persons 55 years and older.

Data from the 1980 Census Public Use Microdata Sample (PUMS), from Census Bureau surveys and population projections, from the Internal Revenue Service, and froin the California Department of Finance provide the basis for this analysis. These data are presented in tabular summaries by age cohort, income category, state of origin, etc. Projections of future migration are developed from these data based on scenarios or extrapolation of current rates. While Department of Defense information :.. used to project military retirement, this analysis is not tied to the overall analysis of retirement-related migration based on PUMS data. While not stated in the report, the military retirement model covers migration that is apparently also included in the general migration projections. 
This report concentrates on descriptive summary and presentation of demographic data. It demonstrates that income from nonlocal sources is a small but potentially increasing proportion of total Clark County income. In-migrants of all ages are more likely to participate in the labor force than their Nevadan counterparts, so it is sitt clear whether the attraction to Nevada is primarily economic or amenity-based. 
Author(s) Popper, F.J.

Date 1983

Title $\quad$ LP/HC and LULUs: The Political Uses of Risk Analysis in Land-Use Planning

Reference Risk Analysis, 3(4):255-263

\title{
KEY WORDS
}

Risk analysis. Hazardous wastes. Disamenities.

\begin{abstract}
The author notes the significance and prevalence of locally unwanted land uses, or LULUs, and the fact that many LULUs are unpopular because of their low-probability, highconsequence $(\mathrm{lp} / \mathrm{hc})$ risks. He suggests that LULUs occur because the costs of a facility are experienced inequitably by its proximate neighbors, while its benefits are shared over a much wider area. Land-use planners and political decision-makers do not typically employ lp/hc risk analysis in their work with LULUs for a variety of reasons, including the perceived high degrees of uncertainty regarding the probabilities in the model and the inability of $\mathrm{lp} / \mathrm{hc}$ risk analysis to include the questions of alternatives to the facility or the equity of the costs and benefits. Rather, planners, decision-makers, and the public tend to focus only on consequences, which leads to their aversion to LULUs. The article concludes with suggestions for making $\mathrm{lp} / \mathrm{hc}$ risk analysis more politically informed.
\end{abstract}


Author(s) Schachter, J., and P.G. Althaus

Date $\quad 1982$

Title Neighborhood Quality and Climate as Factors in U.S. Net Migration Patterns, 1974-1976

Reference American Journal of Economics and Sociology, 41(4):387.400

\title{
KEY WORDS
}

Migration. Amenities.

\begin{abstract}
Studies which attempt to establish the importance of neighborhood quality as determinants of migration have sometimes generated inconclusive results. The authors suggest that one reason is that objective measures of neighborhood quality, as opposed to subjective measures, have been employed. The use of objective measures such as local crime rates, the percentage of the local housing stock that is unsound, and the number of physicians per capita has been necessitated by the lack of any direct measure of household perceptions.
\end{abstract}

The authors employ the Annual Housing Survey (now called the American Housing Survey) to construct three separate subjective indices. The first ranks overall neighborhood quality based upon the mean subjective rankings of residents of the city. The second measures the perceived existence of undesirable conditions in the neighborhood (e.g., crime, litter, odors, streets in need of repair, rundown housing, inadequate housing, commercial and industria establishments, and heavy traffic) using rankings from city residents. The third index measures perceived inadequacy of government services (e.g., schools, public transportation, fire protection, police protection, and street lighting), again using resident rankings. Rankings are measured for 60 metropolitan areas between 1974 and 1976. Also considered as control variables are measures of climate and local economic conditions.

Perceived neighborhood quality is seen to have a positive and significant influence on net in-migration into metropolitan areas. Likewise, undesirable neighborhood conditions induce significant net out-migration. Finally, perceived inadequate public services do not significantly affect net metropolitan migration rates. Among the control variables considered, both climate and economic opportunities are found to be important determinants of net migration. 
Author(s) Schachter, J., and P.G. Althaus

Date $\quad 1989$

Title An Equilibrium Model of Gross Migration

Reference Journal of Regional Science, 29(2):143-160

\title{
KEY WORDS
}

Migration. Amenities.

\begin{abstract}
Since the late $1970 \mathrm{~s}$, a debate has arisen as to the underlying motivation for migration. Using an equilibrium model assumes that regional labor markets are in equilibrium and hence that migration occurs when demand for site-specific amenities is changed (e.g., in association with income- or age-related preferences for climatic amenities). When an equilibrium is attained, net migration is zero (in-migration and out-migration flows are equal). The authors develop a model which relates underlying in-migration and outmigration functions to an equilibrating regional labor market. Deviations from equilibrium. result in adjustments of in-migration and out-migration flows which serve to re-establish equilibrium. Amenities and government services are expected to increase gross in-migration and reduce gross out-migration rates. The reverse is expected of disamenities and statewide taxes.

The authors test this model using gross interstate migration of whites over the 1975-1980 period. Consistent with expectations, mild winter climate is treated as an amenity enhancing in-migration while reducing out-migration. Conversely, higher taxes reduce in-migration and increase out-migration. One anomaly is related to government service spending which unexpectedly reduces in-migration and increases out-migration rates. This may result from higher spending on crime reduction in high-crime states.
\end{abstract}


Author(s) Sjaastad, L.A.

Date 1962

Title The Costs and Returns of Human Migration

Reference Journal of Political Economy, 70(5):80-93

\title{
KEY WORDS
}

Migration.

\begin{abstract}
The author notes that significant interregional income differentials exist between states (using 1950 data), while at the same time, a substantial volume of inte state migration took place. This raises the question as to whether in fact migration is efficiont from an economic perspective. In other words, does migration serve to reallocate resources to narrow income differentials over space?
\end{abstract}

The author suggests that the answer to this is yes, although the simple correlation between net migration and income differentials may be weak. Rather, it may be preferable to consider gross migration flows which are disaggregated by at least age and occupation, since labor markets are so stratified. If all industries in a region have depressed wages, then net out-migration would narrow wage differentials. However, if some industries have depressed wages, while others have labor shortages, and hence experience relatively high wages, then net migration may be near zero. That is, gross in-migration in the occupation with relatively high wages may offset gross out-migration in the industry with relatively low wages.

The author develops a model in which migration is viewed as investment in human capital. This requires an accounting of the various costs and benefits associated with migration. On the cost side, the migrant incurs monetary and nonmonetary costs from migration. The mowetary costs include increases in expenditure for food, lodging, and transportation necessitated by migration. Nonmonetary costs include foregone earnings incurred while traveling, searching, and learning a new job. In addition, psychic costs are borne by the migrant, since people may be reluctant to leave familiar surroundings, as well as family and friends. The author notes that foregone earnings represent a real resource cost, while the psychic costs do not. Thus, the latter should not be used in a rate of return calculation. However, it is clear that these costs do influence resource allucation, since they determine the individual decision to migrate.

Benefits from migration can also generate monetary and nonmonetary returns. Nonmonetary benefits arise from preftrences for one location over another. For example, better climate may make a location preferable. These nonmonetary benefits should be treated analogously 
to nonmonetary costs. Monetary returns include any increment to the real earnings stream. This increment may result from a change in nominal earnings, a change in costs of employment, a change in prices, or some combination of the three effects.

A comparison of age-specific rural out-migration from the Midwest with gross migration rates for the United States supports the hypothesis that migration can be viewed in investment terms. Specifically, migration rates from the rural Midwest are higher at early years and fall off much faster than do rates for the United States as a whole. The author contends that this results from two factors, both related to the investment motive of migrants. First, costs of migration are likely to be much higher for rural migrants, since they are more likely to incur the cost of retraining. Second, the investment in nontransferable rural skills is made at an earlier stage for rural workers than are the skills for the general U.S. population. 
$\begin{array}{ll}\text { Author(s) } & \text { Slovic P., B. Fischoff, and S. Lichtenstein } \\ \text { Date } & 1981 \\ \text { Title } & \text { Perception and Acceptability of Rish from Energy Systems }\end{array}$

Reference Advances in Environmental Psychology, 3:155-170

\title{
KEY WORDS
}

Risk perception. Nuclear power.

\begin{abstract}
The article makes some basic assumptions about perception and risk from previous research. The first premise is that limitations exist when it comes to working out a problem. Intelligent people are not rational when decisions have to be made judging probabilities, developing predictions, or dealing with uncertainty. Bias exists when considering probabilities. The most frequent events are the easier to recollect than not-so-frequent events. Also, "likely occurrences" are more readily conceived than unlikely occurrences.
\end{abstract}

The second premise is that remembering or imagining a hazard influences the perception of risk. Kates (1962) found that people are "strongly conditioned by their immediate past... seeing the future as a mirror of that past." People tend to overestimate the frequency of dramatic and sensationalized events, whereas they would underestimate events that kill one at a time, such as diabetes.

Both lay people and experts are guilty of being overconfident about risk perception. This is why it is difficult to change someone's mind about risk even if there is "evidence." First impressions build and deform the way evidence is understood. If new evidence agrees with the person's beliefs, then the information is viewed as being "reliable and informative." Contrary evidence is viewed as being "unreliable, erroneous, or unrepresentative."

People have various reasons for their perception of nuclear power. Some perceive the benefits to be low and risks too high. Others don't see nuclear power as a necessity for energy production or fear release of radiation. People view nuclear acciderts as being "uncontrollable, lethal, and catastrophic." A perception gap exists between representatives of the nuclear industry and the general public. The nuclear industry believes that only a small amount of damage would be likely in the case of an accident. 
There are two reasons given for people having such a negative perception of nuclear power: technical reality and psychological reality. Nuclear power is a new technology and little is known about the risks. Risk estimates are based on models and mathematical equations, not empirical observation. Experts can present their results, but it doesn't convince the pubic because experts have made errors in the past. 
Author(s) Slovic, P., M. Layman, and J.H. Flynn

Date $\quad 1990 \mathrm{a}$

Title Images of a Place and Vacation Preferences: Implications of the 1989 Surveys for Assessing the Economic Impacts of a Nuclear Waste Repository in Nevada

Reference State of Nevada, Nuclear Waste Project Office, Las Vegas, NWPO-SE-030-90

\title{
KEY WORDS
}

Nuclear waste. Imagery.

\begin{abstract}
ABSTRAC'T
Three telephone surveys were conducted in late 1989 to elicit images associated with various state and cities and relate those images to vacation preferences and behavior. Similar questions were used with respondents from Southern California, the United States, and Phoenix. The Phoenix respondents had previously responded to a similar survey and were included to provide a basis for evaluating the stability of images over time. Respondents were asked for six images that they associate with each of four cities or states. They were also presented with ten categories of images (e.g., crime, outdoor recreation) and were asked to rate the strength of association between these images and each location. Because so few people revealed nuclear images associated with Nevada in the first Phoenix survey, "nuclear" was included among the images rated.

Preliminary analysis of the data indicate that both the elicited images and the image ratings have predictive value for vacation location preferences and vacation behavior. Based on summarization of the data using image scores, the authors conclude that images are relatively stable. The $r$ value for correlation of state image scores across surveys is .42 and for cities $r=.52$.

Using logit analysis, image scores were strongly related to past vacation experience and, in the Phoenix retest group, image scores were related to subsequent vacation locations, controlling for previous vacations, previous residence, and the presence of friends and family. Nuclear images were strongest for Nevada of the locations studied but were "not significantly correlated with the vacation preference ranking or the past vacation history in Nevada."
\end{abstract}


Author(s) Slovic, R., M. Layman, N. Kraus, J. Chalmers, G. Gesell, and J. Filynn

Date $\quad 1989$

Title Percetved Rish, Stigma, and Potential Economic Impacts of a High-Level Nuclear Waste Repository in Nevada

Reference State of Nevada, Nuclear Waste Project Office, Las Vegas, NWPO-SE-023-89, July

\section{KEY WORDS}

Perceived risk. Nuclear waste.

\section{ABSTRACT}

Findings on several separate research efforts addressing repository impacts on tourism, migration, and business location decisions are combined here. The research was designed to measure environmental imagery associated with locations, show the relationship between imagery and location choice, and describe potential impacts of altered images.

Individual location preferences were found to be somewhat predictable from area images using image score summaries. About $10 \%$ of respondents associated nuclear imagery with Nevada, and for these, its mean preference ranking among the four states was lower than for the remaining respondents. Respondents who associated nuclear imagery were more likely to know the location of the Nevada Test Site. Preference rankings were found to be relatively sensitive to changes in image scores. In a subgroup analysis, the relationship of images to location preference was found to be the same for those with a highly positive image of gambling $\ldots$ it was for others. Image scores were positively correlated with previous visits to Nevada. Results were similar for each of the surveys.

Two telephone surveys, each of 400 Phoenix, Arizona, residents, elicited images for four locations and solicited preferences for the locations as places to vacation, work, or retire. A similar survey dealing with business location was carried out with a national sample of business executives. Images were scored by respondents on a five-point scale and a predictive model of location preference was developed based on the imagery scores. Reliability of the findings was confirmed by varying scoring methods.

Images associated with cities and states were found to be predictive of location preferences for both personal and business purposes. Preference rankings were sensitive to relatively small changes in the positive or negutive values of images. Nuclear images are extremely negative, and for some people, awareness of Nevada Test Site activity is associated with low preferences for Nevada. These findings are taken to support the proposition that the Yucca Mountain project will negatively affect the Nevada economy. 
Author(s) Wlldavsky, A., and K. Duku

Date $\quad 1990$

Title Theories of Rtsh Perception: Who Fears What and Why?

Reference Daedalus, fall isaue:41-60

\section{KEY WORDS}

Risk perception.

\section{ABSTRACT}

The authors contrast a variety of social sciunce th sories (e.g., knowledge theory, personality theory, economic theory, political theory, and cultural theory) of the causes of public controversy over risks and hazards. They test these theories for perceptions of risk associated with technology and the environment, war, social deviance, and economic troubles with data from risk perception data archives, which provide survey measures for each theory, plus the individuals' perceptions of the risks and benefits of 25 technologies.

The findings show that the "cultural" theory best explains variation in risk perceptions, especially in comparison to self-rated knowledge, perceptual accuracy, and personality differences. Cultural biases, in terms of egalitarianism, individualism, and hierarchy, which are related loosely to both personality differences and political orientation (liberal vs. conservative) are the best predictors of the level of concern with technological risks, Specifically, they find that egalitarians are most concerned with technological and environmental risks, hierarchists fear social deviance most, and individualists worry most about risks of war. The authors conclude by citing findings of other surveys to the effect that culture and political idenlogy are the best predictors of public views of environmental hazards and technological risks. 

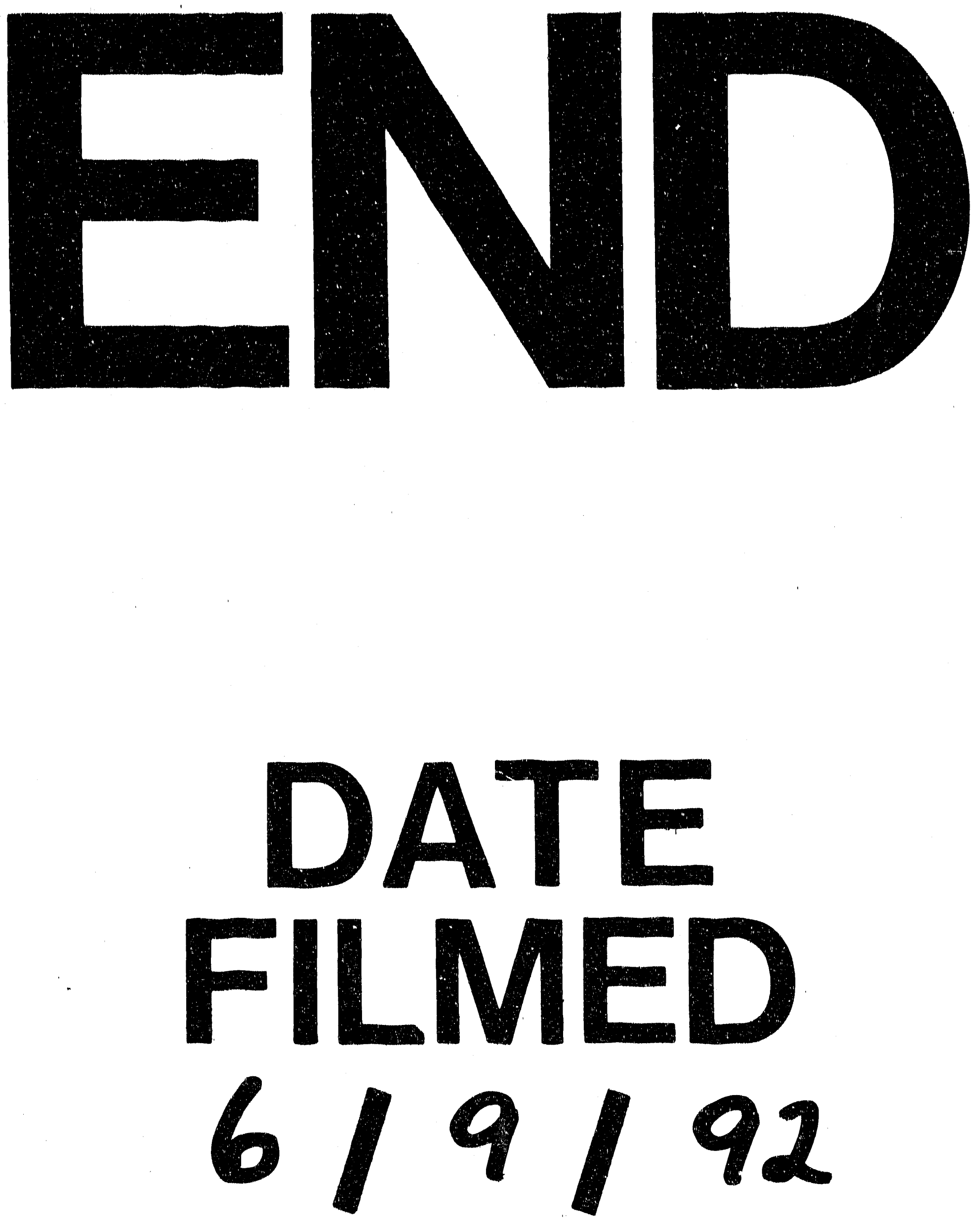
